Article

\title{
Towards Practical Application of Verticillium isaacii Vt305 to Control Verticillium Wilt of Cauliflower: Exploring Complementary Biocontrol Strategies
}

\author{
Silke Deketelaere ${ }^{1}$, Katrijn Spiessens ${ }^{2}$, Sabien Pollet ${ }^{3}$, Lien Tyvaert ${ }^{1}$, Luc De Rooster ${ }^{2}$, \\ Danny Callens ${ }^{3}$, Soraya C. França ${ }^{1,4}$ and Monica Höfte ${ }^{1, *(D)}$ \\ 1 Laboratory of Phytopathology, Department of Plants and Crops, Faculty of Bioscience Engineering, \\ Ghent University, Coupure Links 653, B-9000 Ghent, Belgium; silke.deketelaere@ugent.be (S.D.); \\ schoonbaert-tyvaert@hotmail.com (L.T.); soraya.franca@biobestgroup.com (S.C.F.) \\ 2 Research Station for Vegetable Production npo, Duffelsesteenweg 101, B-2860 Sint-Katelijne-Waver, Belgium; \\ katrijn.spiessens@telenet.be (K.S.); luc.de.rooster@proefstation.be (L.D.R.) \\ 3 Inagro vzw, Ieperseweg 87, B-8800 Rumbeke-Beitem, Belgium; sabien.pollet@inagro.be (S.P.); \\ danny.callens@inagro.be (D.C.) \\ 4 R\&D Department, Biobest Group NV, Ilse Velden 18, B-2260 Westerlo, Belgium \\ * Correspondence: monica.hofte@ugent.be; Tel.: +32-9-264-6017
}

Received: 30 September 2020; Accepted: 26 October 2020; Published: 30 October 2020

check for updates

\begin{abstract}
Verticillium wilt is one of the most important diseases of cauliflower and can lead to serious economic losses. In this study, two complementary strategies were explored to employ the antagonistic capacity of Verticillium isaacii towards Verticillium wilt of cauliflower. The first strategy focused on introducing $V$. isaacii Vt305 by artificial inoculation of cauliflower plantlets at the nursery stage. Two inoculum types (spores and microsclerotia of $V$. isaacii Vt305) and different concentrations of microsclerotia were tested in greenhouse and field trials. Seed treatment with 500 microsclerotia seed $^{-1}$ led to a satisfying biocontrol level of Verticillium wilt. In addition, the PHYTO-DRIP ${ }^{\circledR}$ system was successful in delivering the microsclerotia to cauliflower seeds. The second strategy relied on the stimulation of the natural $V$. isaacii populations by rotating cauliflower with green manures and potato. Four green manure crops and potato were tested during multiple field experiments. Although these crops seemed to stimulate the $V$. isaacii soil population, this increase did not result in a control effect on Verticillium wilt of cauliflower in the short term. Importantly, our results indicate that the use of green manures is compatible with the application of $V$. isaacii $\mathrm{Vt} 305$ as biocontrol agent of Verticillium wilt in cauliflower.
\end{abstract}

Keywords: Verticillium longisporum; biological control; Verticillium isaacii; cauliflower; endophytes; soil-borne pathogen; green manure

\section{Introduction}

The soil-borne pathogen Verticillium longisporum (C. Stark) Karapapa, Bainbr. \& Heale causes serious vascular disease in cauliflower (Brassica oleracea var. botrytis L.). The disease was first reported in coastal California (USA) in 1990 [1] and nearly 10 years later in Belgium [2]. Symptoms observed in Verticillium-infested fields are asymmetric chlorosis of the leaves, wilting, stunted growth, and vascular discoloration of the roots and stem [1,2]. Cauliflower is one of the most important field vegetables in Belgium with a production surface area of more than 5700 ha in 2020 [3]. Verticillium wilt can lead to serious economic losses in cauliflower as both the quality and yield of the heads are reduced and is therefore a major threat to cauliflower production in Belgium. 
The application of biocontrol agents might be a valuable and ecofriendly control strategy of Verticillium wilt that conforms to the integrated pest management (IPM) approach [4]. Only few bacterial isolates with biocontrol activity against $V$. longisporum in oilseed rape have been reported [5-8].

França et al. observed a negative correlation between Verticillium wilt and the presence of Verticillium tricorpus-like organisms in a Belgian cauliflower field [9]. Although these organisms morphologically resemble Verticillium tricorpus I. Isaac, phylogenetic analysis revealed that at least some of them belong to Verticillium isaacii Inderb. et al. [10]. In fact, the isolate Vt305, obtained from this suppressive cauliflower field in Belgium, was identified as V. isaacii [9]. Further research in controlled conditions has shown that Vt305 behaves as endophyte in cauliflower plants and can protect them against Verticillium wilt [11]. These results indicated that $V$. isaacii $\mathrm{Vt} 305$ is a promising biocontrol agent of Verticillium wilt of cauliflower.

Towards practical application of putative beneficial $V$. isaacii, two complementary biocontrol strategies were explored in this study. The first strategy was based on introducing $V$. isaacii $\mathrm{Vt} 305$ by artificial inoculation of cauliflower plantlets at the nursery stage. The second strategy relied on the stimulation of the natural $V$. isaacii populations by rotating cauliflower with green manures and potato. França et al. found that rotation of cauliflower with potato increased the density of $V$. tricorpus-like organisms in the Verticillium wilt-suppressive cauliflower field [9]. Interestingly, it has also been reported that cropping of Verticillium-resistant potato clones was accompanied by increases of bacterial antagonists and moreover resulted in 8-50 fold increases of $V$. tricorpus compared to a susceptible potato cultivar [12]. Use of green manure crops has been considered as an important practice in agroecological farming systems. Green manures offer substantial benefits to the soil, including increased organic matter and nutrients, improved soil structure, and weed and erosion control [13]. The strategy of using green manures to manipulate the indigenous soil microbial community in an attempt to achieve disease control is gaining increased interest. Increasing the density and diversity of pathogen-inhibitory microorganisms, such as fluorescent Pseudomonas, Streptomycetes and non-pathogenic Fusarium spp. through the incorporation of green manures has been shown in several studies [14-17]. The green manure crops tested in this study are already frequently used in the rotation system of cauliflower, except for sticky nightshade. Ryegrass (Lolium spp. L.) has been recommended as a lignin-rich amendment to reduce Verticillium density in soil [2,9]. Phacelia tanacetifolia Benth, member of the Boraginaceae Juss. plant family, is a popular green manure crop in rotations with vegetable crops and is considered as a good catch crop to reduce nitrogen leaching. Phacelia has been proposed as green manure crop to reduce Verticillium wilt of hop plants [18] and it is therefore interesting to test this crop in rotation with cauliflower. Sticky nightshade (Solanum sisymbriifolium Lam.) has been suggested as a trap crop for potato cyst nematodes [19]. Since this nematode is also a problem in Belgian fields and cauliflower is often rotated with potato, $S$. sisymbriifolium is an interesting green manure crop in our cauliflower fields. Black oat (Avena strigosa Schreb.) is a rapid growing leafy cereal crop and therefore very useful to suppress weeds. As a cover crop, black oat has been shown to resist or inhibit root-knot nematodes [20]. Because of these characteristics, black oat is commonly used as green manure crop in Belgium.

The present study aimed to evaluate the capacity of $V$. isaacii $\mathrm{Vt305}$ to protect cauliflower in greenhouse and field conditions. Two inoculum types (spores and microsclerotia of $V$. isaacii Vt305) and different doses of microsclerotia were applied on cauliflower seedlings. In addition, the PHYTO-DRIP ${ }^{\circledR}$ system was evaluated for microsclerotia application on seeds at nursery. A second objective of this study was to investigate the effect of green manure crops (ryegrass, Phacelia, Solanum sisymbriifolium and black oat) and potato on the Verticillium microsclerotia densities in soil and the consequence of potential changes in Verticillium soil populations on Verticillium wilt in cauliflower. Finally, the combined effect of green manure crops and artificial inoculation of cauliflower with $V$. isaacii Vt305 on Verticillium wilt of cauliflower was investigated. 


\section{Results}

\subsection{Production of $V$. isaacii Vt305 Microsclerotia}

The production of microsclerotia on modified soil extract agar covered with a cellophane disc was found to be a fast and consistent production method on lab scale. Huge amounts of microsclerotia were formed per plate after 14 days of incubation in the dark. On average this method yielded $8466.7 \pm 472.6$ microsclerotia $\mathrm{mg}^{-1}$ powder corresponding to $(8.5 \pm 0.5) \times 10^{6}$ microsclerotia per plate. Importantly, microsclerotia could be collected separately, which allows a correct dosing.

\subsection{Efficacy of V. isaacii Vt305 in Greenhouse Conditions}

Two greenhouse experiments were carried out to assess the effect of $V$. isaacii $\mathrm{Vt305}$ against Verticillium wilt in soil naturally infested with $V$. longisporum. V. isaacii Vt305 was applied as spores or as microsclerotia. Inoculation with spores was done by dipping the potting soil blocks of four-week-old plantlets in a spore suspension $\left(10^{6}\right.$ spores $\left.\mathrm{mL}^{-1}\right) 10$ days before transplantation to the naturally infested soil. Microsclerotia (MS) suspensions were applied onto the cauliflower seeds in different concentrations (100 MS, $500 \mathrm{MS}$, and $1000 \mathrm{MS}$ ) and 30 days later plants were transplanted to the

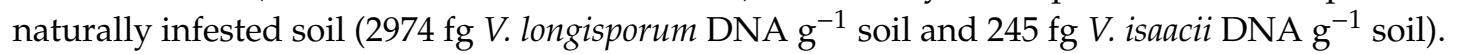

Dipping the cauliflower plantlets in a spore suspension of $V$. isaacii Vt305 significantly suppressed disease symptoms of Verticillium wilt in cauliflower compared to the untreated control (Figure 1A): $25 \%$ of the cauliflower plants showed severe vascular discoloration (score 3 ), while $80 \%$ of the untreated control plants received a score of 3.

Prior to transplantation, the hypocotyls of the cauliflower plantlets inoculated with microsclerotia were sampled to monitor the colonization by $V$. isaacii Vt305. V. isaacii DNA was detected in the hypocotyls of all sampled plants when a dose of $100 \mathrm{MS}$ per seed was applied. At doses of $500 \mathrm{MS}$ and 1000 MS, V. isaacii was present at detectable levels in the hypocotyls of four out of six plants. For all treatments only small amounts of $V$. isaacii DNA were detected, which indicates that 30 days after sowing $V$. isaacii $\mathrm{Vt} 305$ could not colonize the hypocotyl to a high extent.

Pre-inoculation with $V$. isaacii Vt305 microsclerotia clearly reduced the vascular discoloration of the stem (Figure 1B). This reduction was statistically significant when seeds were treated with 500 MS or 1000 MS. Vascular discoloration was prevented in more than half of the stems when 1000 MS was applied. Moreover, a dose-effect was observed; a higher dose of $V$. isaacii Vt305 microsclerotia resulted in lower scores for vascular discoloration of the stems.

The colonization of the hypocotyl by V. longisporum was significantly reduced by V. isaacii Vt305 at 28 days post transplantation ( $\mathrm{dpt}$ ) to naturally infested soil when the biocontrol agent was applied as spores (Figure 1C). The colonization of the cauliflower plants by $V$. longisporum was quantified at different time points during the greenhouse experiment in which microsclerotia were used as inoculum of $V$. isaacii Vt305. No significant differences in V. longisporum colonization were detected in roots and hypocotyls between control plants and inoculated plants at $33 \mathrm{dpt}$ and $68 \mathrm{dpt}$. At harvest (103 dpt) a significant lower amount of $V$. longisporum DNA was found in the hypocotyl of plants inoculated with $V$. isaacii Vt305 (Figure 1D), while comparable levels were detected in the roots of all plants. Colonization by $V$. longisporum did not differ much between the plants treated with different concentrations of the $V$. isaacii Vt305 microsclerotia suspension.

In both greenhouse experiments, $V$. isaacii was also detected in the roots and hypocotyls of the control plants after transplantation in naturally infested soil. The amount of $V$. isaacii present in the naturally infested soil (245 $\mathrm{fg}^{\mathrm{DNA} \mathrm{g}}{ }^{-1}$ soil) was sufficient to colonize the control plants, but did not offer protection against Verticillium wilt (Figure 1). It was furthermore remarkable that at time points close to harvest, the hypocotyls of control plants were colonized to a higher extent by $V$. isaacii species than the hypocotyls of plants pre-inoculated with V. isaacii Vt305 (data not shown). 


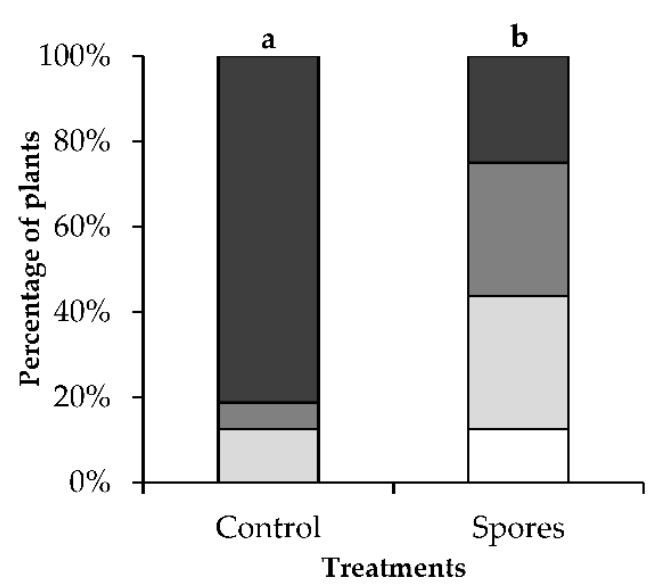

(A)

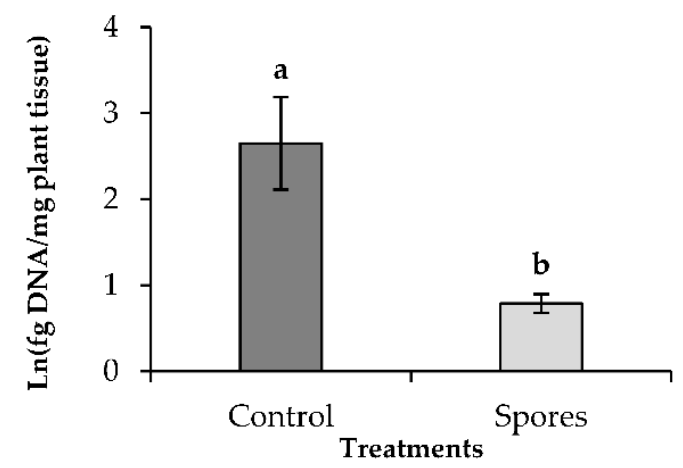

(C)

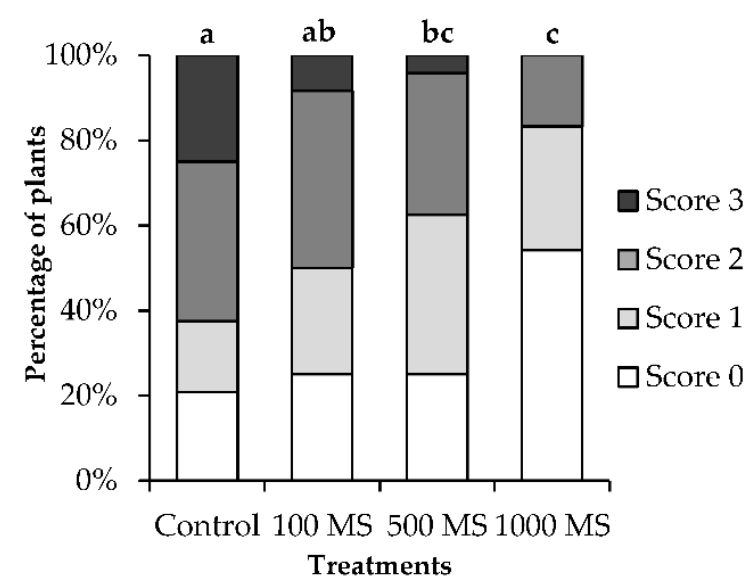

(B)

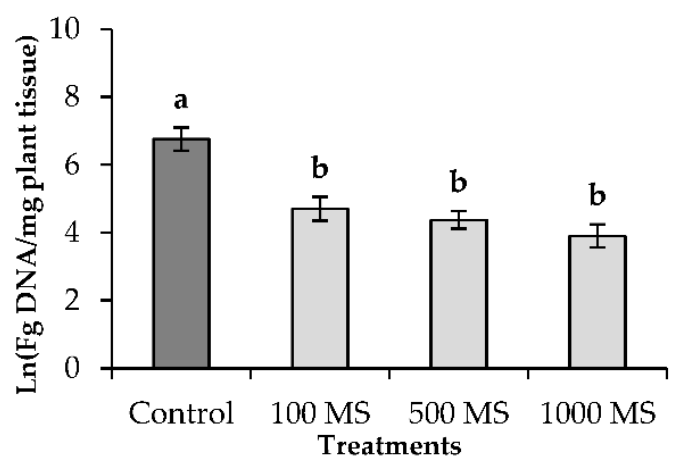

(D)

Figure 1. Biocontrol of Verticillium wilt in cauliflower in greenhouse conditions when V. isaacii Vt305 was applied as spores or as microsclerotia (MS). (A) Vascular discoloration 70 days post transplantation (dpt) to naturally infested soil of cauliflower plants inoculated with $V$. isaacii Vt305 via root dip in a spore suspension with a concentration of $10^{6}$ spores $\mathrm{mL}^{-1}$ or mock-inoculated via root dip in sterile water in case of the control; (B) Vascular discoloration $103 \mathrm{dpt}$ to naturally infested soil of cauliflower plants inoculated with $V$. isaacii $\mathrm{Vt} 305$ via seed treatment with a microsclerotia suspension applied in different concentrations $\left(100,500\right.$, or 1000 microsclerotia plant $\left.{ }^{-1}\right)$ or mock-inoculated via seed treatment with sterile water in case of the control. Results on vascular discoloration are shown as percentage of plants $(n=12)$ with a specific score for vascular discoloration: $0=$ no vascular discoloration; $1=$ vascular discoloration of $<50 \%$ of stem length; 2 = vascular discoloration of $50-75 \%$ of stem length; and 3 = vascular discoloration of $76-100 \%$ of stem length. (C) Amount of detected V. longisporum DNA in the hypocotyl $28 \mathrm{dpt}$ when $V$. isaacii Vt305 was applied as spores; (D) Amount of detected $V$. longisporum DNA in the hypocotyl $103 \mathrm{dpt}$ when $V$. isaacii Vt305 was applied as microsclerotia. Values are means \pm standard error $(n=6)$. Colonization data were $\ln$ transformed before statistics. Bars indicated with the same letter are not significantly different according to a Mann-Whitney U-test in case of the vascular discoloration and according to a Tukey test in case of the colonization data $(p<0.05)$.

\subsection{Efficacy of V. isaacii Vt305 in Field Conditions}

2.3.1. Application of Different Doses of V. isaacii Vt305 Microsclerotia at Three Locations in Three Different Cauliflower Cultivars

For the field experiments, cauliflower seeds were manually dripped with a microsclerotia suspension of $V$. isaacii Vt305 or with tap water (control). After growing the plants for four weeks in 
the nurseries, they were planted in naturally infested fields. At harvest, the vascular discoloration of cauliflower stems was scored and a disease index was calculated. The quality of the cauliflower curds was also evaluated to determine the percentage of marketable curds.

The effect of applying different concentrations of $V$. isaacii Vt305 microsclerotia on Verticillium wilt was tested during two field experiments at locations in Ardooie (cultivar Clapton) and Bornem (cultivar Korlanu) in 2014. Seed treatment with microsclerotia significantly reduced the disease index in Ardooie regardless of the dose (Table 1). When treated with V. isaacii Vt305, more than half of the plants showed no or minor vascular discoloration. The main differences between treatments were found in the number of plants with severe vascular discoloration (score of 3). On average, $24.5 \%$ of the control plants were given a score of 3, while after treating the seeds with $300 \mathrm{MS}$ of $\mathrm{V}$. isaacii Vt 305 only $11.1 \%$ of the plants received a score of 3 . When doses of $500 \mathrm{MS}$ or 1000 MS were applied, no stems or only $2.2 \%$ of the stems showed severe vascular discoloration, respectively. In practice, cauliflower plants with scores of 1 and 2 for vascular discoloration still produce marketable curds in most cases. Only $75.6 \%$ of the evaluated control plants produced curds that met the market standards in the experiment in Ardooie. After applying V. isaacii Vt305 the number of marketable cauliflower curds was significantly higher and there were almost no yield losses when seeds were treated with 500 and 1000 MS. There was no significant effect of V. isaacii Vt305 application on the disease index in Bornem, although a dose of 500 MS tended to reduce the disease index compared to the control treatment (Table 1). This could be explained by the significant increase of the number of healthy plants after pre-inoculation with a dose of 500 MS. Furthermore, it is important to notice that none of the evaluated plants showed severe symptoms (score of 3 ) and no loss of marketable curds occurred. The low disease pressure possibly masked the protective effect of $V$. isaacii Vt305.

Table 1. Biocontrol of Verticillium wilt of cauliflower by $V$. isaacii Vt305 in field conditions at three locations (Ardooie and Bornem in 2014 and Oppuurs in 2015). Cauliflower seeds (cv Clapton, Korlanu or Clarina) were treated with water (control) or a microsclerotia (MS) suspension of $V$. isaacii Vt305 at different concentrations: 300 MS, 500 MS, or 1000 MS per seed. At harvest (76 dpt in Ardooie, $73 \mathrm{dpt}$ in Bornem and $66 \mathrm{dpt}$ in Oppuurs), vascular discoloration of the stems was scored: $0=$ no vascular discoloration; $1=$ vascular discoloration of $<50 \%$ of stem length; $2=$ vascular discoloration of $50-75 \%$ of stem length; and $3=$ vascular discoloration of $76-100 \%$ of stem length. For each location the percentage of plants with a specific score for vascular discoloration (mean of 4 plots \pm standard error), the disease index (\%) (mean of 4 plots \pm standard error) and the percentage of marketable cauliflower curds are shown.

\begin{tabular}{|c|c|c|c|c|c|c|c|}
\hline & Cultivar & $\begin{array}{c}\text { \% Plants } \\
\text { Score } 0\end{array}$ & $\begin{array}{c}\% \text { Plants } \\
\text { Score } 1\end{array}$ & $\begin{array}{l}\text { \% Plants } \\
\text { Score } 2\end{array}$ & $\begin{array}{c}\text { \% Plants } \\
\text { Score } 3\end{array}$ & $\begin{array}{c}\text { Disease } \\
\text { Index }(\%)^{1}\end{array}$ & $\begin{array}{c}\text { Marketable } \\
\text { Curds (\%) }\end{array}$ \\
\hline \multicolumn{8}{|l|}{ Ardooie } \\
\hline Control & Clapton & $4.4 \pm 2.2 \mathrm{a}^{2}$ & $22.2 \pm 2.2 \mathrm{a}$ & $48.9 \pm 4.4 \mathrm{a}$ & $24.5 \pm 2.2 \mathrm{a}$ & $64.4 \pm 2.2 \mathrm{a}$ & $75.5 \pm 2.2 \mathrm{a}$ \\
\hline $300 \mathrm{MS}$ & Clapton & $17.8 \pm 8.0 \mathrm{~b}$ & $37.8 \pm 4.5 \mathrm{ab}$ & $33.3 \pm 11.5 \mathrm{a}$ & $11.1 \pm 4.4 \mathrm{ab}$ & $45.9 \pm 7.4 b$ & $88.9 \pm 4.4 b$ \\
\hline $500 \mathrm{MS}$ & Clapton & $11.1 \pm 2.2 \mathrm{ab}$ & $42.2 \pm 5.9 b$ & $46.7 \pm 7.7 \mathrm{a}$ & $0.0 \pm 0.0 \mathrm{c}$ & $45.2 \pm 3.2 b$ & $100.0 \pm 0.0 c$ \\
\hline $1000 \mathrm{MS}$ & Clapton & $13.3 \pm 3.8 \mathrm{ab}$ & $48.9 \pm 8.9 b$ & $35.6 \pm 4.4 \mathrm{a}$ & $2.2 \pm 2.2 b c$ & $42.2 \pm 2.2 b$ & $97.8 \pm 2.2 c$ \\
\hline \multicolumn{8}{|l|}{ Bornem } \\
\hline Control & Korlanu & $48.0 \pm 10.6 \mathrm{a}$ & $45.0 \pm 8.5 \mathrm{a}$ & $7.0 \pm 2.5 \mathrm{a}$ & $0.0 \pm 0.0 \mathrm{a}$ & $19.7 \pm 4.3 \mathrm{a}$ & $100.0 \pm 0.0 \mathrm{a}$ \\
\hline $300 \mathrm{MS}$ & Korlanu & $50.0 \pm 10.4 \mathrm{a}$ & $45.0 \pm 5.7 \mathrm{a}$ & $5.0 \pm 5.0 \mathrm{ab}$ & $0.0 \pm 0.0 \mathrm{a}$ & $18.3 \pm 5.1 \mathrm{a}$ & $100.0 \pm 0.0 \mathrm{a}$ \\
\hline $500 \mathrm{MS}$ & Korlanu & $72.0 \pm 6.9 \mathrm{~b}$ & $27.0 \pm 6.0 \mathrm{~b}$ & $1.0 \pm 1.0 \mathrm{~b}$ & $0.0 \pm 0.0 \mathrm{a}$ & $9.7 \pm 2.6 \mathrm{a}$ & $100.0 \pm 0.0 a$ \\
\hline $1000 \mathrm{MS}$ & Korlanu & $57.0 \pm 27.0 \mathrm{a}$ & $40.0 \pm 12.0 \mathrm{ab}$ & $3.0 \pm 1.9 \mathrm{ab}$ & $0.0 \pm 0.0 \mathrm{a}$ & $15.3 \pm 5.0 \mathrm{a}$ & $100.0 \pm 0.0 \mathrm{a}$ \\
\hline \multicolumn{8}{|l|}{ Oppuurs } \\
\hline Control & Korlanu & $10.7 \pm 6.3 \mathrm{ab}$ & $39.3 \pm 8.1 \mathrm{a}$ & $36.9 \pm 7.1 \mathrm{a}$ & $13.1 \pm 4.9 \mathrm{a}$ & $50.8 \pm 3.7 \mathrm{a}$ & $86.9 \pm 4.9 \mathrm{a}$ \\
\hline $500 \mathrm{MS}$ & Korlanu & $9.6 \pm 5.1 \mathrm{a}$ & $57.1 \pm 3.9 b$ & $21.4 \pm 5.0 \mathrm{~b}$ & $11.9 \pm 7.1 \mathrm{a}$ & $45.2 \pm 6.0 \mathrm{ab}$ & $88.1 \pm 7.1 \mathrm{a}$ \\
\hline Control & Clarina & $15.5 \pm 9.0 \mathrm{ab}$ & $48.8 \pm 3.0 \mathrm{ab}$ & $35.7 \pm 10.4 \mathrm{a}$ & $0.0 \pm 0.0 \mathrm{~b}$ & $40.1 \pm 6.4 b$ & $100.0 \pm 0.0 \mathrm{~b}$ \\
\hline $500 \mathrm{MS}$ & Clarina & $21.4 \pm 12.4 b$ & $60.7 \pm 7.6 b$ & $15.5 \pm 4.1 b$ & $2.4 \pm 1.4 \mathrm{~b}$ & $32.9 \pm 6.2 c$ & $97.6 \pm 1.4 b$ \\
\hline
\end{tabular}

1 The disease index was calculated based on the scores for vascular discoloration via the formula of Townsend-Heuberger $\left[\left(0^{*} a+1^{*} b+2^{*} c+3^{*} d\right) /\left(e^{*} f\right)\right]^{*} 100$; letters $a, b, c$, and $d$, are the numbers of plants for each disease score, the letter e is the highest score $(=3)$, and $\mathrm{f}$ represent the number of observations $(=20)$. ${ }^{2}$ For each location, values with the same letter within the same column do not differ significantly according to the Mann-Whitney U-test $(p<0.05)$. 
During the field experiment in Oppuurs in 2015, cauliflower seeds of the cultivars Korlanu and Clarina were treated with a microsclerotia suspension of $V$. isaacii $\mathrm{Vt} 305$ at a rate of $500 \mathrm{MS}$ per seed. This concentration of microsclerotia was chosen because it led to satisfying biocontrol of Verticillium wilt in the field experiments carried out in 2014. Application of V. isaacii Vt305 resulted in more plants with scores of 0 or 1 for vascular discoloration for both cultivars (Table 1), but significant differences were found only in the cultivar Clarina.

\subsubsection{Application of $V$. isaacii Vt305 Microsclerotia with the PHYTO-DRIP ${ }^{\circledR}$ System}

Cauliflower seeds of the cultivar Clapton with different coatings were inoculated with $V$. isaacii Vt305 microsclerotia using the PHYTO-DRIP ${ }^{\circledR}$ system (Syngenta, Basel, Switzerland). With this system a single drop of the microsclerotia suspension was dripped onto each seed during the seeding process resulting in a dose of $360 \mathrm{MS}$ per seed. Seeds of the control plants were dripped with tap water. The use of the PHYTO-DRIP ${ }^{\circledR}$ system resulted in easy and fast application of the V. isaacii Vt 305 microsclerotia suspension on the cauliflower seeds. The microsclerotia did not obstruct the filters of the system and no other difficulties were observed. Four-week-old plantlets were subsequently planted in a field with a history of Verticillium wilt of cauliflower located in Ardooie. Table 2 shows that the seed treatment with $V$. isaacii Vt305 microsclerotia protected cauliflower against Verticillium wilt. At harvest (98 dpt), more than $90 \%$ of the plants pre-inoculated with $V$. isaacii Vt305 were scored 0 or 1 . Control plants showed more severe vascular discoloration and most plants received a score of 2 or 3 . These differences in disease severity are illustrated by the disease indexes, which were more than $50 \%$ lower when the seeds were treated with $V$. isaacii Vt305. No loss of marketable curds was found in plants inoculated with $V$. isaacii Vt305. Importantly, the conventional seed coatings with fungicides did not influence the biocontrol effect of $V$. isaacii Vt305 against Verticillium wilt in cauliflower.

Table 2. Biocontrol of Verticillium wilt of cauliflower in field conditions at Ardooie in 2013 when the PHYTO-DRIP ${ }^{\circledR}$ system was used to deliver microsclerotia of $V$. isaacii Vt305 on seeds. Cauliflower seeds (cv Clapton) with coatings (seed coating 1 = iprodione and thiram; seed coating 2 = fipronil, iprodione, thiram and metalaxyl-M) or without coating were treated with water (control) or a suspension of $V$. isaacii Vt305 microsclerotia (MS) at a concentration of 360 MS per seed using the PHYTO-DRIP ${ }^{\circledR}$ system. At harvest (98 dpt), vascular discoloration of the stems was scored: $0=$ no vascular discoloration; $1=$ vascular discoloration of $<50 \%$ of stem length; 2 = vascular discoloration of $50-75 \%$ of stem length; and 3 = vascular discoloration of $76-100 \%$ of stem length. For each treatment the percentage of plants $(n=10)$ with a specific score for vascular discoloration, the disease index $(\%)$ and the disease incidence $(\%)$ are shown.

\begin{tabular}{cccccccc}
\hline $\begin{array}{c}\text { Seed } \\
\text { Treatment }\end{array}$ & $\begin{array}{c}\text { Seed } \\
\text { Coating }\end{array}$ & $\begin{array}{c}\text { \% Plants } \\
\text { Score 0 }\end{array}$ & $\begin{array}{c}\text { \% Plants } \\
\text { Score 1 }\end{array}$ & $\begin{array}{c}\text { \% Plants } \\
\text { Score 2 }\end{array}$ & $\begin{array}{c}\text { \% Plants } \\
\text { Score 3 }\end{array}$ & $\begin{array}{c}\text { Disease } \\
\text { Index (\%) }\end{array}$ & $\begin{array}{c}\text { Marketable } \\
\text { Curds (\%) }\end{array}$ \\
\hline Water & No coating & $0.0 \mathrm{a}^{2}$ & $0.0 \mathrm{a}$ & $90.0 \mathrm{a}$ & $10.0 \mathrm{a}$ & $70.0 \mathrm{a}$ & $90.0 \mathrm{a}$ \\
Water & Coating 1 & $0.0 \mathrm{a}$ & $20.0 \mathrm{ab}$ & $60.0 \mathrm{a}$ & $20.0 \mathrm{a}$ & $66.7 \mathrm{a}$ & $80.0 \mathrm{a}$ \\
Water & Coating 2 & $0.0 \mathrm{a}$ & $0.0 \mathrm{a}$ & $90.0 \mathrm{a}$ & $10.0 \mathrm{a}$ & $70.0 \mathrm{a}$ & $90.0 \mathrm{a}$ \\
Vt305 & No coating & $20.0 \mathrm{a}$ & $70.0 \mathrm{c}$ & $10.0 \mathrm{~b}$ & $0.0 \mathrm{a}$ & $30.0 \mathrm{~b}$ & $100.0 \mathrm{a}$ \\
Vt305 & Coating 1 & $10.0 \mathrm{a}$ & $90.0 \mathrm{c}$ & $0.0 \mathrm{~b}$ & $0.0 \mathrm{a}$ & $30.0 \mathrm{~b}$ & $100.0 \mathrm{a}$ \\
Vt305 & Coating 2 & $30.0 \mathrm{a}$ & $60.0 \mathrm{bc}$ & $10.0 \mathrm{~b}$ & $0.0 \mathrm{a}$ & $26.7 \mathrm{~b}$ & $100.0 \mathrm{a}$ \\
\hline
\end{tabular}

1 The disease index was calculated based on the scores for vascular discoloration via the formula of Townsend-Heuberger $\left[\left(0^{*} a+1^{*} b+2^{*} c+3^{*} d\right) /\left(e^{*} f\right)\right]^{*} 100$; letters $a, b, c$, and $d$, are the numbers of plants for each disease score, the letter e is the highest score $(=3)$, and $\mathrm{f}$ represents the number of observations $(=10)$. ${ }^{2}$ Values with the same letter within the same column do not differ significant according to the Mann-Whitney U-test $(p<0.05)$. 
2.4. Effect of Potato and Green Manure Crops on Verticillium Soil Populations and Verticillium Wilt of Cauliflower

\subsubsection{Colonization of Green Manure Crop Residues by V. isaacii, V. longisporum, and V. dahliae}

By determining the colonization of the crop residues of Phacelia, ryegrass, sticky nightshade, and black oat by $V$. isaacii, $V$. longisporum and $V$. dahliae, we aimed to estimate their contribution to the build-up of soil inoculum of these three Verticillium species. After growing the crops in naturally infested soil, fragments of these crops were put in nylon bags and buried in the soil to mimic incorporation in the field. $V$. isaacii and $V$. dahliae were detected in the crop residues of all tested crops (Table 3). In particular, the residues of ryegrass were highly colonized by $V$. isaacii and those of sticky nightshade by $V$. dahliae. A detectable colonization by $V$. longisporum of the crop residues was only found for black oat. These results indicated that incorporation of Phacelia, ryegrass, sticky nightshade, and black oat might increase the soil inoculum of $V$. isaacii and $V$. dahliae. Importantly, there were no indications that the tested crops, apart from black oat, will stimulate $V$. longisporum in the soil.

Table 3. Colonization of the green manure residues by Verticillium spp. Green manures were grown for four months in soil naturally infested with $V$. isaacii, $V$. longisporum, and $V$. dahliae, subsequently cut into small pieces (shoot and roots) and put in nylon bags that were buried in the soil for three months. The colonization of these plant residues by the three Verticillium species was quantified via real time-PCR. Samples of three bags were pooled before real time-PCR analysis and values are the detected amounts of Verticillium DNA in these pooled samples.

\begin{tabular}{cccc}
\hline Crop Residue & $\begin{array}{c}\text { V. isaacii DNA } \\
\text { (fg DNA mg } \\
\text { Plant Tissue) }\end{array}$ & $\begin{array}{c}\text { V. longisporum DNA } \\
\text { (fg DNA mg-1 } \\
\text { Plant Tissue) }\end{array}$ & $\begin{array}{c}\text { V. dahliae DNA } \\
\text { (fg DNA mg }\end{array}$ \\
$\begin{array}{c}\text { Plant Tissue) } \\
\text { Phacelia }\end{array}$ & 673 & - & 1304 \\
Ryegrass & 75,644 & - & 1531 \\
Sticky nightshade & 7405 & - & 102,809 \\
Black oat & 106 & 80 & 944 \\
\hline
\end{tabular}

2.4.2. Effect of Potato and Green Manure Crops on Soil Populations of Verticillium spp. and the Impact on Verticillium Wilt in Cauliflower

The effect of potato, Phacelia, ryegrass, sticky nightshade, and black oat on the soil populations of $V$. isaacii, V. longisporum, and V. dahliae and on Verticillium wilt in the following crop cauliflower was tested during field experiments in 2013 and 2014 at different locations in Ardooie and Puurs. Plots left fallow before the cultivation of cauliflower were used as control.

The inoculum densities of $V$. isaacii, $V$. longisporum and $V$. dahliae on the different time points are shown per location for both years in Figures A1 and A2. During the field experiment in Ardooie in 2013, a significant increase of the $V$. isaacii population was detected for all five cover crop systems and the largest increase was observed when potato preceded cauliflower. In the same year, the increase in the soil population of $V$. isaacii was significant after Phacelia and potato in the field in Puurs. The level of $V$. longisporum soil inoculum did not change significantly during the field experiments in 2013 for all five cover crop systems. In 2013, a significant increase of the $V$. dahliae population was observed in the field in Ardooie, irrespective of the cover crop system. The level of $V$. dahliae also increased over time in Puurs. Here, the increase was statistically significant when a cover crop preceded the cultivation of cauliflower.

Concerning the field experiments carried out in 2014, it was remarkable that the initial inoculum densities of all three Verticillium species were already quite high compared to 2013. The soil population of $V$. isaacii did not change much in all five cover crop systems during the field experiments in Ardooie and Puurs in 2014. In Ardooie, a decreasing trend was observed in the inoculum density of $V$. longisporum when ryegrass, black oat, or potato were cultivated before cauliflower. No big changes in the level of $V$. longisporum were detected in Puurs. In both fields, the V. dahliae inoculum density 
remained more or less stable when plots were left fallow before cultivating cauliflower. When a green manure crop or potato preceded cauliflower, a rather decreasing trend was observed regarding the $V$. dahliae population. Surprisingly, the soil population of $V$. dahliae significantly decreased after potato in the fields of Ardooie and Puurs. This was unexpected because potato is a host plant of $V$. dahliae. In addition, when black oat was used as a cover crop, the decrease of $V$. dahliae was statistically significant in the field in Ardooie.

After harvest of the curds, the vascular discoloration of the cauliflower stems was scored on a scale of 0 to 3 (Figure 2). In the first year (2013) of the field experiment in Ardooie, cauliflower stems exhibited less vascular discoloration after the tested crops compared to fallow. This reducing effect on Verticillium wilt was, however, not significant. Due to a severe clubroot infestation, it was not possible to score the vascular discoloration of the stems from the field in Ardooie in 2014. The disease pressure was low in the field of Puurs during the experiment in 2013 and no significant differences in disease severity of Verticillium wilt of cauliflower were observed between the five cropping systems. During the field experiment in Puurs in 2014, the disease pressure was quite high and only ryegrass and Phacelia seemed to lower Verticillium wilt compared to fallow. However, these effects were again not statistically significant. In the short term, the tested crops did not have a significant effect on Verticillium wilt of cauliflower. To determine the long term effects of these cropping systems field experiments over several years need to be carried out.

\subsection{Combined Effect of Green Manure Crops and Treatment of the Cauliflower Seeds with V. isaacii Vt305 on} Verticillium Wilt of Cauliflower

The effect of combining green manure crops and seed treatment of cauliflower with $V$. isaacii Vt305 on Verticillium wilt was tested during a field experiment in a grower's field located in Puurs. A dose of 500 microsclerotia per seed was used to treat the cauliflower seeds. At harvest of the cauliflower curds, vascular discoloration of the stems was evaluated. The percentage of affected plants and the disease index (disease severity) are shown in Figure 3. The cultivation of black oat, Phacelia, or ryegrass alone did not significantly reduce Verticillium wilt compared to the fallow plots. Pre-inoculation of the cauliflower plants with $V$. isaacii $\mathrm{Vt} 305$, however, resulted in a significant reduction of the disease severity and incidence in all four cover crop systems. The combination of Phacelia and seed treatment with $V$. isaacii Vt305 of cauliflower resulted in the best protection against Verticillium wilt as no vascular discoloration was observed in the evaluated cauliflower stems. The artificial inoculation with $V$. isaacii Vt305 was clearly the determining factor in the reduction of Verticillium wilt. The soil of the different plots was also sampled to determine the inoculum densities of $V$. isaacii, V. longisporum, and V. dahliae at different time points (Figure A3). In this way, we could determine if differences in Verticillium disease were the result of changes in the ratio between soil populations of $V$. isaacii and V. longisporum. However, the results of the soil analyses did not correlate with the observed disease pressure of $V$. longisporum in the different plots. The high variability in disease pressure between the different plots could not be linked to differences in the soil populations of $V$. isaacii and V. longisporum. 


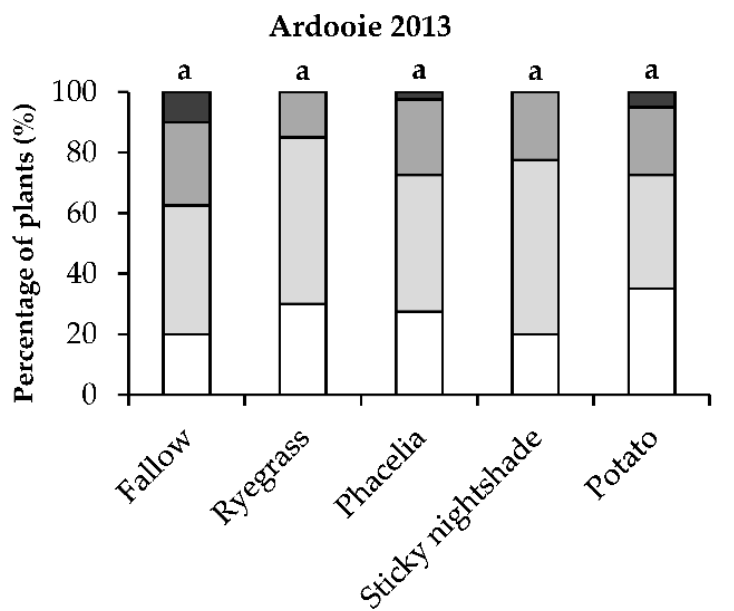

Cover crop

(A)

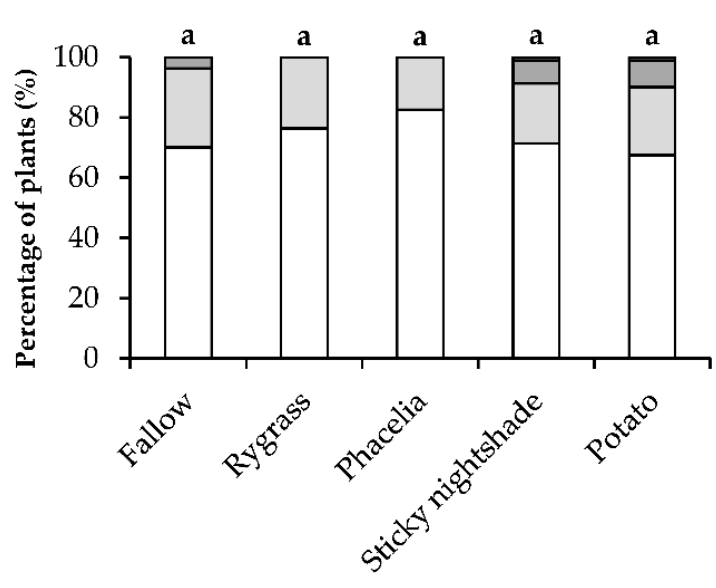

Cover crop

(B)

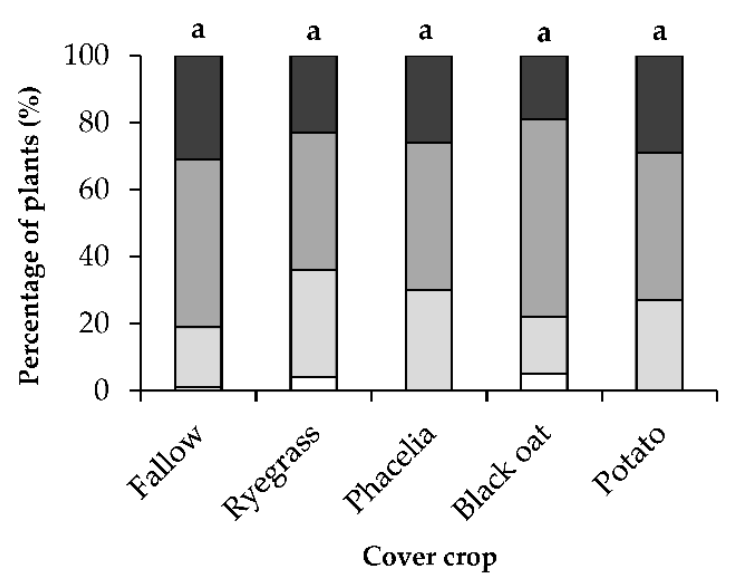

$\square$ Score $0 \quad \square$ Score $1 \quad \square$ Score $2 \quad \square$ Score 3

(C)

Figure 2. Verticillium wilt of cauliflower in grower's fields located in Ardooie and Puurs during the growing seasons of 2013 and 2014 in five cover crop systems. (A) Vascular discoloration of the cauliflower stems in the field at Ardooie in 2013; (B) Vascular discoloration of the cauliflower stems in the field at Puurs in 2013; (C) Vascular discoloration of the cauliflower stems in the field at Puurs in 2014. Data are shown as the percentage of plants $(n=20)$ with a specific score for vascular discoloration at harvest of the cauliflower curds: $0=$ no vascular discoloration; $1=$ vascular discoloration of $<50 \%$ of stem length; 2 = vascular discoloration of $50-75 \%$ of stem length; and $3=$ vascular discoloration of $76-100 \%$ of stem length. Bars indicated with the same letter are not significantly different according to a Mann-Whitney U-test $(p<0.05)$. 


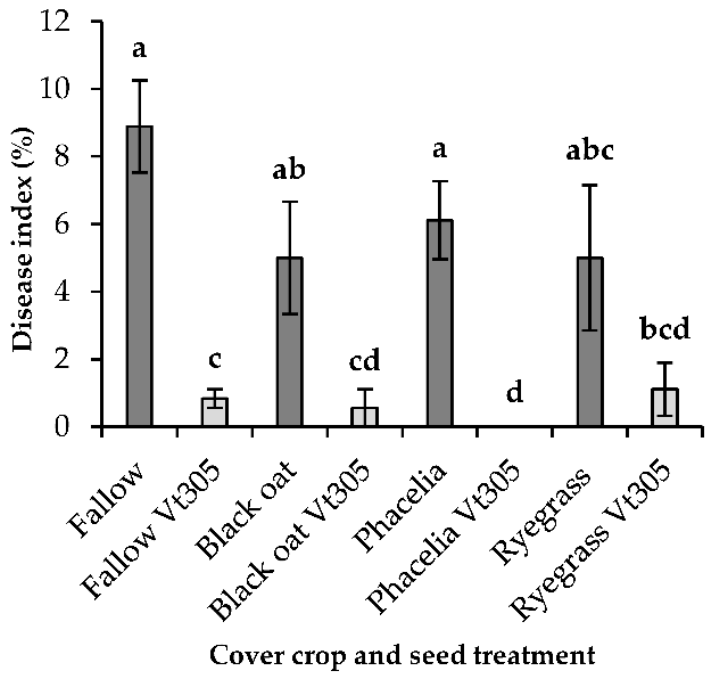

(A)

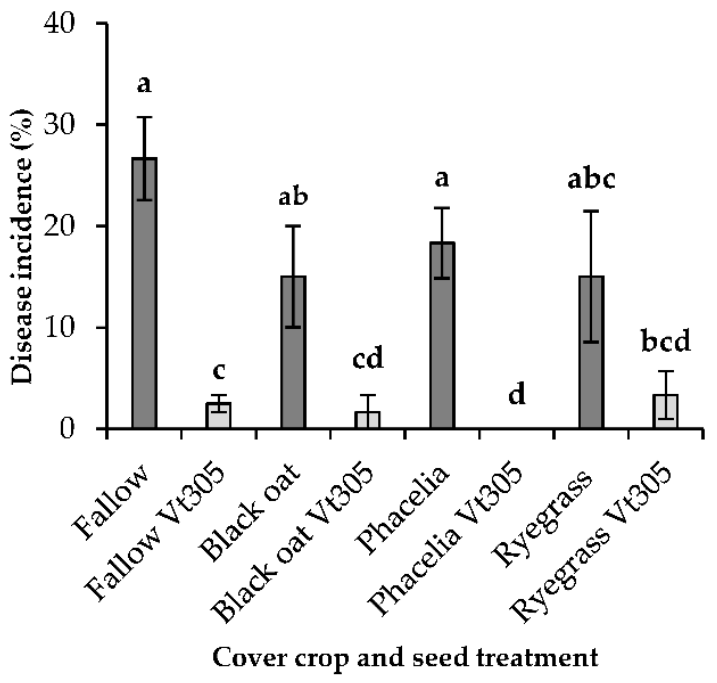

(B)

Figure 3. Effect of treatment with $V$. isaacii Vt305 on Verticillium wilt of cauliflower in a grower's field in Puurs during the growing season of 2015 in four cover crop systems. Cauliflower seeds (cultivar Clarina) were treated with tap water or a microsclerotia (MS) suspension (500 MS per seed) indicated with 'Vt305'. (A) Disease index of the cauliflower plants at harvest. The disease index was calculated based on the scores for vascular discoloration via the formula of Townsend-Heuberger $\left[\left(0^{*} a+1^{*} b+\right.\right.$ $\left.\left.2^{*} c+3^{*} d\right) /\left(e^{*} f\right)\right]^{*} 100$; letters $a, b, c$, and $d$, are the numbers of plants for each disease score, the letter e is the highest score $(=3)$, and $f$ represents the number of observations $(=20)$. (B) Disease incidence of Verticillium wilt. Values are the mean of 4 replicates and the vertical bars represent the standard error of the mean. Bars indicated with the same letter are not significantly different according to a Mann-Whitney test $(p<0.05)$.

\section{Discussion}

The ability of $V$. isaacii Vt305 to protect cauliflower plants against Verticillium wilt in controlled conditions has previously been shown by Tyvaert et al. [11]. In the present work, we have demonstrated that $V$. isaacii Vt305 could also reduce Verticillium wilt of cauliflower in greenhouse and field conditions. Biocontrol of pathogenic Verticillium spp. by non-pathogenic Verticillium isolates has already been shown in cotton [21,22], potato [23,24], tomato [25,26], and lettuce [27]. The protection of plants against virulent Verticillium species by a non-pathogenic relative Verticillium species has been described as cross-protection. Induced resistance, competition for space and nutrients, and plant growth promotion are suggested to be involved in this phenomenon [26,28].

The capacity of $V$. isaacii isolates to form different structures is an interesting characteristic of a biocontrol agent, as this can be useful for application in different systems. Besides the production of conidia, the formation of three different survival structures has been reported for $V$. isaacii isolates [10]. We have shown that both dipping cauliflower plantlets in a conidial suspension of $V$. isaacii Vt305 and treating the seeds with microsclerotia of $V$. isaacii $\mathrm{Vt} 305$ reduced Verticillium wilt. However, we believe that microsclerotia are more interesting structures for practical applications than conidia. These robust surviving structures resist unfavorable conditions and remain viable for a long time [29], which are desirable traits for future formulation and application in practice. Because of the persistence of the microsclerotia in the soil, it is crucial to verify that $V$. isaacii $V t 305$ is not pathogenic for a wide variety of plants. Via artificial inoculation trials we could already confirm that $V$. isaacii Vt305 does not cause either vascular discoloration or other symptoms of Verticillium wilt in potato, chrysanthemum, oilseed rape, broccoli, pepper, tomato, hop, Phacelia, and sticky nightshade (unpublished results).

Early application of biocontrol isolates, before pathogen infection, has been reported to result in better protection [21,24,27]. Application of $V$. isaacii Vt305 microsclerotia to the seed delivers the 
biocontrol agent in close vicinity to the plant roots and allows early colonization of the seedlings. Inoculating seeds with microsclerotia of $V$. isaacii Vt305 using the PHYTO-DRIP ${ }^{\circledR}$ system was compatible with the production system and quality requirements of plant nurseries producing cauliflower plantlets. Moreover, treating the seeds with a suspension of $V$. isaacii $\mathrm{Vt305}$ microsclerotia was compatible with the conventional coatings of the cauliflower seeds with fungicides and insecticides. However, the tested seed coatings with thiram and iprodione are currently no longer approved by the EU and additional experiments will be necessary if new coatings are used. From a commercial point of view, it is important to produce the greatest quantity of viable propagules with the best quality as cheaply as possible [30]. We have evidence that $V$. isaacii microsclerotia can be produced on a large scale in a cost-effective manner using solid-state fermentation. When developing the formulation, it is important that the final product is convenient to use, safe to handle and have adequate shelf life.

In the field experiments, $V$. isaacii Vt305 reduced Verticillium wilt significantly in the cauliflower cultivars Clapton and Clarina, but not in the cultivar Korlanu (Tables 1 and 2, Figure 3). These results might indicate an effect of the cultivar on the success of $V$. isaacii Vt305 to control Verticillium wilt in cauliflower. A cultivar effect might be due to differences in susceptibility to V. longisporum. It is plausible that in very susceptible cauliflower cultivars a significant reduction of Verticillium wilt is more difficult to achieve than in more resistant cultivars. Debode et al [31] have observed clear differences in susceptibility to $V$. longisporum among European cauliflower cultivars. However, data from cauliflower cultivar trials, carried out by the research stations Inagro and PSKW (Belgium), showed a comparable susceptibility to $V$. longisporum of the cultivars tested in our study. The different levels of biocontrol observed in the various cauliflower cultivars might also be the result of differences in degree of colonization by $V$. isaacii $\mathrm{Vt} 305$ of the cultivars or the result of cultivar-specific responses involved in the biocontrol. Hence, it is essential for the practical application of $V$. isaacii Vt305 to evaluate more (commercial) cauliflower cultivars, regarding their colonization by this biocontrol isolate.

In the field trials in 2013 regarding the effect of potato and green manure crops on Verticillium spp. densities in the soil, a significant increase of the $V$. isaacii soil population was observed in all five cover crop systems at both locations, except for the fallow treatment in the field of Puurs. This was in contrast with the results in 2014, where in none of the crop systems a significant increase was detected. Remarkably, the initial levels of $V$. isaacii in the different plots were much lower in 2013 compared to these in 2014. This might suggest that the extent of increase in soil population of $V$. isaacii depends on the initial density. In line with our results, Wiggins and Kinkel showed that the enrichment in streptomycete densities was density-dependent [16]. Soils with relatively low streptomycete densities had greater increases in streptomycete densities following incorporation of green manure crops than soil with relatively high streptomycete densities. The development and viability of Verticillium microsclerotia may be influenced by environmental factors, such as temperature, humidity, and microbial populations in the soil [32-34]. Interannual differences in the Verticillium inoculum densities observed in our field experiments might therefore also be due to different weather conditions in 2013, 2014, and 2015 (Figure A4). Compared to the field experiments in 2014 and 2015, the initial level of Verticillium soil inoculum was low in the field experiments in 2013 (Figures A1-A3). This observation might be explained by the low temperatures during the months February and March in 2013. The maximum temperature in March $2013\left(6.1^{\circ} \mathrm{C}\right)$ was even a negative record of the last 30 years. These low temperatures might have negatively affected the formation of microsclerotia in the crop residues. In addition, the release of Verticillium microsclerotia in the soil might have been reduced as a result of low microbial activity at these low temperatures in 2013.

Because fluctuations in the Verticillium populations were also noticed in the fallow treatments, it was difficult to draw conclusions about the effect of the crop systems on population densities of the three Verticillium species. Seasonal fluctuation of Verticillium microsclerotia density in soil was observed in cauliflower fields in Belgium. Peaks in Verticillium microsclerotia in spring and summer were followed by drop-offs in autumn [9]. In our study, we did not observe such seasonal fluctuation. The use of a different detection method (qPCR instead of a plating technique) might partly account 
for this. In addition, the sequence of crops and the timing of cultural practices differed between both studies. These factors might influence the formation, release from crop residues and germination of Verticillium microsclerotia and thus the amount of (active) microsclerotia present in the soil.

In this study, growing the different green manure crops or potato followed by incorporating the crop residues was not effective in reducing Verticillium wilt of cauliflower. Other studies reported a significant reduction of Verticillium wilt on potato after green manure treatments $[17,35,36]$. However, disease control was not consistent throughout these studies reflecting varying conditions and circumstances under which the experiments were conducted. Obviously, factors such as soil type, pathogen inoculum densities, composition of the soil microbiome, and the green manure species used influence the final effect of green manure treatments.

The differences in disease pressure of Verticillium wilt on cauliflower observed between plots could not only be explained by differences in Verticillium soil densities. This might be partially attributed to the lack of discrimination between living and dead material, or active and dormant propagules when using a qPCR method to study soil fungi. Hence, the detection of non-viable Verticillium microsclerotia, resulting in an overestimation of the soil inoculum, cannot be ignored. It is, however, generally assumed that DNA derived from dead cells degrades fairly rapidly in natural moist soil due to microbial activity, suggesting that the bias due to detection of dead microsclerotia might be of less importance [37-39]. Nonetheless, detection of DNA of dormant Verticillium microsclerotia is inevitable. Besides the Verticillium density, disease pressure is also influenced by other factors such as weather conditions, soil characteristics and other microorganisms present in the soil. For example, it was reported that the incidence of Verticillium wilt on potato was negatively correlated to soil organic matter [40]. A study of Wiggens and Kinkel showed that potatoes grown in soils with greater proportions of antagonistic streptomycetes had lower Verticillium wilt ratings [17].

During the field experiment in which the application of $V$. isaacii Vt305 was tested in four cover crop systems, treating the cauliflower seeds with $V$. isaacii Vt 305 was essential to decrease disease severity and incidence. No significant reduction of Verticillium wilt in cauliflower was obtained by growing the different green manure crops without treatment of the seeds with V. isaacii Vt305. However, the green manure crops ryegrass, Phacelia, and black oat did not negatively affect the biocontrol effect of $V$. isaacii Vt305 towards Verticillium wilt in cauliflower either. The compatibility of cropping these green manure crops with the application of $V$. isaacii $\mathrm{Vt} 305$ in cauliflower is an important result regarding the use of this biocontrol agent in practice to control Verticillium wilt.

Additional field trials to test green manure treatments during two or more successive years, would be useful to assess the long-term effect of green manure crops on soil populations of Verticillium and the potential impact on Verticillium wilt of cauliflower. In addition, monitoring other microorganisms during these studies by high-throughput sequencing could be helpful in understanding the effect of green manure crops on Verticillium wilt in cauliflower. Exploration of the diversity of $V$. isaacii populations in our soils will generate more knowledge about the proportion of antagonistic isolates in these populations and thus the potential of increasing the indigenous $V$. isaacii soil population as a strategy to suppress Verticillium wilt of cauliflower. Better insight in the diversity of the indigenous $V$. isaacii soil population is also necessary to estimate the risk of stimulating pathogenic $V$. isaacii isolates by cultivating specific crops and green manures. Recent studies have shown that $V$. isaacii possesses a wide range of ecological lifestyles including pathogenic and endophytic isolates [41-43].

The results of this work demonstrated that $V$. isaacii $\mathrm{Vt} 305$ has potential to be developed as a biocontrol product to control Verticillium wilt in cauliflower. Furthermore, our results showed that combining the treatment of cauliflower seeds with $V$. isaacii $\mathrm{Vt} 305$ and the use of green manure crops were compatible. Although green manure crops alone were not effective in reducing Verticillium wilt in cauliflower in the short term, they did not have a negative effect on the biocontrol effect of $V$. isaacii Vt305. Moreover, green manure crops are generally known to improve soil health and are 
therefore interesting to integrate in a sustainable and environmentally sound management strategy of Verticillium wilt.

\section{Materials and Methods}

\subsection{Verticillium isaacii Isolate Vt305 and Inoculum Preparation}

Verticillium isaacii Vt305 was isolated from soil of a cauliflower field suppressive to Verticillium wilt in Ardooie, Belgium [9].

Conidial suspension was prepared from plates of two-week-old cultures incubated on PDA at room temperature in the dark, by adding sterile distilled water to the plate and gently rubbing the surface of the colony with a sterile spatula. Finally, the conidial suspension was filtered through a sterile cheesecloth and adjusted to the required concentration.

Microsclerotia of $V$. isaacii $\mathrm{Vt} 305$ were produced according to the method described by López-Escudero et al. [44] with modifications. Briefly, $0.8 \mathrm{~mL}$ conidial suspension $\left(10^{6}\right.$ conidia $\mathrm{mL}^{-1}$ ) was plated onto each modified soil extract agar plate covered with a sterilized permeable cellophane disc. After 14 days of incubation at room temperature in the dark, microsclerotia were formed on the cellophane sheet. Microsclerotia were scraped off the cellophane with a sterile scalpel, air-dried for several hours in sterile conditions and ground with mortar and pestle to a fine powder. To determine the concentration of the microsclerotia powder, a mix of $3 \mathrm{mg}$ of the powder in $30 \mathrm{~mL}$ of sterile water was prepared. The number of microsclerotia in the suspension was then determined in small subsamples $(20 \mu \mathrm{L})$ using a dissecting microscope and converted to the number of microsclerotia present per mg of powder. Final microsclerotia suspensions were prepared prior to application by mixing a specific amount of the microsclerotia powder with water (sterile distilled water in greenhouse experiments and tap water in field experiments).

\subsection{Efficacy of V. isaacii Vt305 in Greenhouse Conditions}

Two experiments were carried out to determine the efficacy of $V$. isaacii Vt305 in greenhouse conditions in which two different inoculum types, spores or microsclerotia, were tested. In both greenhouse experiments cauliflower (Brassica oleracea var botrytis L.) plants of the cultivar Cornell were grown in blocks of potting soil for four weeks prior to transplanting to soil naturally infested with $V$. longisporum. When spores were used to inoculate plants with $V$. isaacii Vt305, soil blocks of

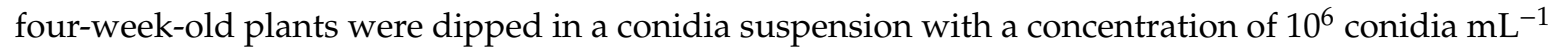
for $30 \mathrm{~min}$. Soil blocks of the control plants were dipped in sterile distilled water water. Ten days after inoculation, each plant together with its soil block was transplanted to a pot (12 L) filled with soil naturally infested with $V$. longisporum. When plants were inoculated with $V$. isaacii Vt305 via microsclerotia, each cauliflower seed was dripped with $0.5 \mathrm{~mL}$ of a microsclerotia (MS) suspension using a pipette. Concentrations of 100,500, and 1000 MS per seed were used. Seeds of the control plants were dripped with sterile distilled water. Thirty days after sowing and inoculation, cauliflower plants were transplanted to pots $(12 \mathrm{~L})$ filled with naturally infested soil. The soil used in both experiments originated from a grower's field in Oppuurs with a history of Verticillium wilt in cauliflower. This soil was sandy loam, $\mathrm{pH}-\mathrm{KCl} 6.8$ and $1.8 \%$ organic carbon. Analysis of the used soil showed the presence

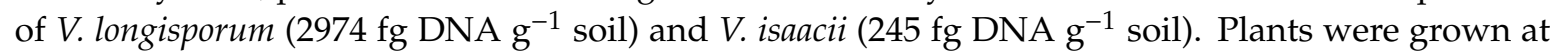
$16-18{ }^{\circ} \mathrm{C}$ and $16 \mathrm{~h}$ of light. During the experiment in which plants were inoculated with $V$. isaacii Vt305 via spores, six plants per treatment were sampled 28 days post transplantation (dpt) to naturally infested soil to quantify the colonization of the hypocotyl by $V$. longisporum via real-time PCR. In case of inoculation with $V$. isaacii $\mathrm{Vt} 305$ via microsclerotia, six plants of each treatment were sampled prior to transplantation to verify the colonization by $V$. isaacii Vt305 of the hypocotyl. To quantify the colonization of the hypocotyl by $V$. longisporum and $V$. isaacii during the experiment, six plants per treatment were sampled at 33, 68, and $103 \mathrm{dpt}$. Vascular discoloration of 12 plants per treatment was 
evaluated at respectively $70 \mathrm{dpt}$ and $103 \mathrm{dpt}$, in the pot experiment with inoculation via spores and the pot experiment with inoculation via microsclerotia.

\subsection{Efficacy of V. isaacii Vt305 in Field Conditions}

Field trials were conducted in grower's fields located at Ardooie (West Flanders), Bornem and Oppuurs (Antwerp) in 2013, 2014, and 2015. Cauliflower has been cultivated frequently in these fields and Verticillium wilt has been observed. For each trial, the soil characteristics of the field, the amount of soil inoculum of $V$. longisporum and $V$. isaacii present in the field, the inoculation method, the inoculum concentration of $V$. isaacii Vt305, the cauliflower cultivar used, and the planting and harvest date of the cauliflower plants are shown in Table 4. In all field experiments, cauliflower plants were inoculated with $V$. isaacii $\mathrm{Vt} 305$ via seed treatment with a microsclerotia suspension. For the field experiments in 2014 and 2015, cauliflower seeds were placed in blocks of potting soil and manually dripped with $0.5 \mathrm{~mL}$ tap water (control) or $0.5 \mathrm{~mL}$ of microsclerotia suspension of $V$. isaacii $\mathrm{Vt} 305$ using a pipette. Different concentrations were used: 300 MS, 500 MS, or 1000 MS per seed. The PHYTO-DRIP ${ }^{\circledR}$ system (Syngenta, Basel, Switzerland) was used to inoculate cauliflower seeds in the field experiment conducted in 2013. During the seeding process in the nursery, a single drop of microsclerotia suspension was dripped onto each seed resulting in a dose of $360 \mathrm{MS}$ of $V$. isaacii Vt305 per seed. Seeds of the control plants were dripped with tap water. Uncoated seeds of the cauliflower cultivars Clapton, Korlanu, and Clarina were used in the field experiments of 2014 and 2015. During the PHYTO-DRIP ${ }^{\circledR}$ field experiment in 2013, uncoated seeds or seeds with two different conventional coatings (coating of iprodione and thiram or coating of fipronil, iprodione, thiram, and metalaxyl-M) of the cauliflower cultivar Clapton were used. Plants were grown for four weeks in the nurseries and subsequently planted in the field. Treatments were arranged in a randomized complete block design with four replicates in the field experiments conducted in 2014 and 2015. Plot sizes were $14.5 \mathrm{~m}^{2}$ (4 rows of 9 plants) in Ardooie, $20 \mathrm{~m}^{2}$ (6 rows of 8 plants) in Bornem and $20 \mathrm{~m}^{2}$ (6 rows of 8 plants) in Oppuurs. During the PHYTO-DRIP ${ }^{\circledR}$ field experiment (2013), plants of each treatment were arranged in four rows of 15 plants in plots of $22.5 \mathrm{~m}^{2}$ (one plot per treatment). In each plot, vascular discoloration was scored in stems of 10 (field experiment 2013) or 20 (field experiments 2014 and 2015) randomly chosen plants after harvest.

\subsection{Colonization of Crop Residues by V. isaacii, V. longisporum and V. dahliae}

The green manure crops Phacelia (cv Natra), ryegrass (cv Danergo), sticky nightshade (cv Pion), and black oat (cv Pratex) were sown in boxes $(60 \mathrm{~cm} \times 40 \mathrm{~cm} \times 24 \mathrm{~cm}$ ) filled with soil naturally infested with Verticillium spp. (977 fg V. isaacii DNA g ${ }^{-1}$ soil, $680 \mathrm{fg}$ V. longisporum DNA g ${ }^{-1}$ soil and $996 \mathrm{fg}$ $V$. dahliae DNA g ${ }^{-1}$ soil). The soil originated from a grower's field located in Ardooie (sandy loam, $\mathrm{pH}-\mathrm{KCl} 5.7$ and $0.9 \%$ organic carbon). Each green manure crop was sown in one box at the sowing density indicated by the seed company. Four months after sowing, plants were removed from the soil (shoot and root) and cut into small fragments of $\pm 2 \mathrm{~cm}$. For each crop, three nylon bags $(5 \mathrm{~cm} \times 5 \mathrm{~cm})$ were filled with the plant fragments and buried at a depth of $10 \mathrm{~cm}$ for three months in the soil of the same box in which the crop had grown. Boxes were regularly watered during the experiment and placed in a non-heated greenhouse compartment.

\subsection{Effect of Potato and Green Manure Crops on Soil Population of Verticillium and the Impact on Verticillium} Wilt in Cauliflower in Field Conditions

Four field trials were carried out at Puurs (Antwerp) and Ardooie (West Flanders) in 2013 and 2014 regarding the effect of potato and green manure crops on Verticillium soil populations and the impact on Verticillium wilt in cauliflower. Table 5 shows the location, the soil characteristics, the cultivated crops preceding cauliflower (green manure crops and potato), and the timing of the cultivation practices for each of the experiments. The same field was used in Ardooie for the consecutive experiments in 2013 and 2014, while in Puurs the experiments were carried out in two different fields. The plot sizes in the experiments in Puurs were respectively $20 \mathrm{~m}^{2}$ and $40 \mathrm{~m}^{2}$ in 2013 and 2014. In the field located 
in Ardooie, each plot had a size of $67.5 \mathrm{~m}^{2}$. Treatments were arranged in a randomized complete block design with four replicates. Green manure crops and potato were incorporated in the soil before planting of the cauliflower plantlets in the plots. The cauliflower cultivar Clarina was used in all field experiments, except in the experiment of Puurs in 2013 where the cultivar Clapton was planted. To monitor the inoculum densities of $V$. isaacii, $V$. longisporum and $V$. dahliae, soil samples were collected at three time points: one week before sowing the green manure crops/potato, one week before the incorporation of the green manure crops/potato, and one week before harvest of the cauliflower heads.

\subsection{Combined Effect of Green Manure Crops and Treatment of the Cauliflower Seeds with V. isaacii Vt305 on Verticillium Wilt of Cauliflower}

The effect of combining green manure crops and treatment of the cauliflower seeds with $V$. isaacii Vt305 on Verticillium wilt of cauliflower was tested during a field experiment in 2015 at Puurs. The location and soil characteristics of the field, the cultivated green manure crops preceding cauliflower, and the timing of the cultivation practices are shown in Table 5. The experimental design was a four-by-two factorial combination of four cover crop systems (fallow, Phacelia, black oat, and ryegrass) and two main crop systems (untreated cauliflower plants and cauliflower plants inoculated with $V$. isaacii $\mathrm{Vt305).} \mathrm{Treatments} \mathrm{were} \mathrm{arranged} \mathrm{in} \mathrm{a} \mathrm{randomized} \mathrm{complete} \mathrm{block} \mathrm{design} \mathrm{with} \mathrm{four} \mathrm{replicates.}$ Plot sizes in the field in Puurs were $35 \mathrm{~m}^{2}$. Green manure crops were incorporated in the soil before planting of the cauliflower plantlets in the plots. To monitor the inoculum densities of $V$. isaacii, $V$. longisporum, and $V$. dahliae, soil samples were collected at three time points: one week before sowing the green manure crops/potato, one week before the incorporation of the green manure crops/potato, and one week before harvest of the cauliflower heads.

Table 4. Overview of the field trials in which the effect of artificial inoculation of cauliflower plants with $V$. isaacii Vt305 on Verticillium wilt was tested. For each experiment, the location, the soil characteristics, the amount of soil inoculum of $V$. longisporum (Vl) and $V$. isaacii (Vi), the inoculation method and inoculum concentration of $V$. isaacii $\mathrm{Vt} 305$ (Vt305), the cauliflower cultivar used, and the planting and harvest date of the cauliflower plants are shown.

\begin{tabular}{|c|c|c|c|c|}
\hline & Trial 1 & Trial 2 & Trial 3 & Trial 4 \\
\hline Location & Ardooie & Bornem & Oppuurs & Ardooie \\
\hline Geographic & 50.95799 & 51.09646, & 51.06842 & 50.95799 \\
\hline coordinates field & 3.18380 & 4.29868 & 4.24148 & 3.18380 \\
\hline Year & 2014 & 2014 & 2015 & 2013 \\
\hline & Sandy & Sandy & Sandy & Sandy \\
\hline Soil type & loam & loam & loam & loam \\
\hline Soil pH-KCl & 5.7 & 6.5 & 6.8 & 5.7 \\
\hline Soil \% Corg & 0.9 & 1.6 & 1.8 & 0.9 \\
\hline $\begin{array}{l}\text { Vl soil inoculum } \\
\text { (fg DNA g }{ }^{-1} \text { soil) }\end{array}$ & 1941 & 358 & 1749 & 231 \\
\hline $\begin{array}{l}\text { Vi soil inoculum } \\
\text { (fg DNA g }{ }^{-1} \text { soil) }\end{array}$ & 268 & 127 & 290 & 232 \\
\hline $\begin{array}{c}\text { Inoculation method } \\
\text { Vt305 }\end{array}$ & $\begin{array}{l}\text { Drip (pipette): } \\
\text { seed }\end{array}$ & $\begin{array}{l}\text { Drip (pipette): } \\
\text { seed }\end{array}$ & $\begin{array}{l}\text { Drip (pipette): } \\
\text { seed }\end{array}$ & $\begin{array}{c}\text { PHYTO-DRIP }{ }^{\circledR:} \\
\text { seed }\end{array}$ \\
\hline Inoculum & 300,500 and 1000 & 300,500 and 1000 & 500 & 360 \\
\hline concentration Vt305 & MS/plant & MS/plant & MS/plant & MS/plant \\
\hline Cauliflower cultivar & Clapton & Korlanu & Korlanu Clarina & Clapton $^{1}$ \\
\hline Cauliflower planting & $05 / 08$ & $25 / 07$ & $22 / 05$ & $31 / 07$ \\
\hline Cauliflower harvest & $20 / 10$ & $06 / 10$ & $27 / 07$ & $06 / 11$ \\
\hline
\end{tabular}

MS: microsclerotia. ${ }^{1}$ Uncoated seeds, seeds coated with iprodione and thiram and seeds coated with fipronil, iprodione, thiram, and metalaxyl-M were used. 
Table 5. Overview of the field trials carried out in 2013, 2014 and 2015 regarding the effect of potato and green manure crops on Verticillium soil population and the impact on Verticillium wilt. The location, the soil characteristics, the cultivated crops preceding cauliflower (green manure crops and potato), and the timing of the cultivation practices are shown.

\begin{tabular}{|c|c|c|c|c|c|}
\hline & Trial 1 & Trial 2 & Trial 3 & Trial 4 & Trial 5 \\
\hline Location & Puurs & Ardooie & Puurs & Ardooie & Puurs \\
\hline Geographic coordinates & 51.06851, & 50.95799, & 51.06753, & 50.95799, & 51.06851, \\
\hline field & 4.25162 & 3.18380 & 4.25180 & 3.18380 & 4.25162 \\
\hline Year & 2013 & 2013 & 2014 & 2014 & 2015 \\
\hline Soil type & Sandy loam & Sandy loam & Sandy loam & Sandy loam & Sandy loam \\
\hline Soil pH-KCl & 6.9 & 5.7 & 7.3 & 5.7 & 6.9 \\
\hline Soil \% $\mathrm{C}_{\text {org }}$ & 1.9 & 0.9 & 2.2 & 0.9 & 1.9 \\
\hline \multirow{4}{*}{ Green manures ${ }_{2}^{1} /$ potato } & Ryegrass & Ryegrass & Ryegrass & Ryegrass & Ryegrass \\
\hline & Phacelia & Phacelia & Phacelia & Phacelia & Phacelia \\
\hline & Sticky nightshade & Sticky nightshade & Black oat & Black oat & Black oat \\
\hline & Potato & Potato & Potato & Potato & \\
\hline $\begin{array}{c}\text { Sowing green } \\
\text { manures/planting } \\
\text { potato }\end{array}$ & $18 / 04$ & $16 / 04$ & $11 / 03$ & $17 / 04$ & $18 / 03$ \\
\hline $\begin{array}{l}\text { Incorporation green } \\
\text { manures/potato }\end{array}$ & $16 / 07$ & $28 / 07$ & $11 / 06$ & $14 / 07$ & $02 / 06$ \\
\hline Cauliflower planting ${ }^{3,4}$ & $30 / 07$ & $30 / 07$ & $07 / 07$ & 05/08 & $17 / 06$ \\
\hline Cauliflower harvest & $04 / 11$ & $23 / 10$ & $01 / 10$ & $03 / 11$ & $14 / 09$ \\
\hline
\end{tabular}

${ }^{1}$ Ryegrass (Lolium multiflorum Lam.) cv Danergo: $60 \mathrm{~kg} / \mathrm{ha}$; Phacelia (Phacelia tanacetifolia Benth.) cv Natra: $10 \mathrm{~kg} / \mathrm{ha}$; Sticky nightshade (Solanum sisymbriifolium Lam.) cv Pion: $3 \mathrm{~kg} /$ ha; Black oat (Avena strigosa Schreb.) cv Pratex $50 \mathrm{~kg} / \mathrm{ha} .{ }^{2}$ Potato (Solanum tuberosum L.) cv Anosta (Puurs and Ardooie) in 2013, and cv Monalisa (Puurs) and cv Première (Ardooie) in 2014: 35,714 tubers/ha. ${ }^{3}$ The cauliflower cultivar Clapton was planted in Puurs in 2013 and in all the other field trials the cauliflower cultivar Clarina was planted. ${ }^{4}$ In field trial 5 (Puurs 2015) cauliflower seeds were treated with a microsclerotia suspension of $V$. isaacii Vt305 (500 MS per seed) or tap water (control).

\subsection{Disease Assessment}

Stems of cauliflower were longitudinally split to score vascular discoloration caused by $V$. longisporum. A scale from 0 to 3 was used, where $0=$ no vascular discoloration; $1=$ vascular discoloration of $<50 \%$ of stem length; 2 = vascular discoloration of $50-75 \%$ of stem length; and $3=$ vascular discoloration of $76-100 \%$ of stem length. The disease index was calculated based on the scores for vascular discoloration via the formula of Townsend-Heuberger $\left[\left(0^{*} a+1^{*} b+2^{*} c+\right.\right.$ $\left.\left.3^{*} \mathrm{~d}\right) /\left(\mathrm{e}^{*} \mathrm{f}\right)\right]^{*} 100$; letters $\mathrm{a}, \mathrm{b}, \mathrm{c}$, and $\mathrm{d}$, are the numbers of plants for each disease score, the letter e is the highest score (=3), and $\mathrm{f}$ represents the number of observations. The quality of the harvested curds was evaluated and expressed as percentage of curds that meet the quality requirements of the market.

\subsection{DNA Extraction from Plant Tissues}

In the greenhouse experiments regarding the efficacy of $V$. isaacii $\mathrm{Vt} 305$, the roots and the hypocotyl (below the cotyledons) were sampled to quantify the colonization by Verticillium spp. In case of the colonization experiment of the crop residues, the contents of three bags were pooled and carefully rinsed with tap water to remove the residual soil prior to DNA extraction. Plant samples were ground with mortar and pestle in liquid nitrogen and DNA was extracted using the Invisorb Spin Plant Mini DNA extraction kit (Invitek). A Nanodrop spectrophotometer was used to measure DNA concentrations and DNA extracts were diluted to a final concentration of $5 \mathrm{ng} \mu \mathrm{L}^{-1}$ prior to real-time PCR analysis.

\subsection{Soil Sampling and Processing to Determine the Inoculum Density}

Twelve soil cores were collected to a depth of $30 \mathrm{~cm}$ from each plot and bulked into a single soil sample per plot. Samples were air dried at room temperature for two weeks. According to the method described by Debode et al. [45], fifty grams of air-dried soil were crumbled and thoroughly mixed with $50 \mathrm{~mL} 70 \%(w t / w t)$ sucrose. After centrifuging the suspension at $2700 \times g$ for $20 \mathrm{~min}$, the resulting supernatant was poured into a vacuum-filtration system (Gelman Sciences, Port Washington, NY, USA) 
over a 20- $\mu \mathrm{m}$ nylon mesh filter (Millipore, Burlington, MA, USA) and rinsed with sterile water. DNA was extracted from the material retained on the filter, using the MoBio Power Soil DNA isolation kit following manufacturer's instructions. DNA concentrations were measured using a Nanodrop spectrophotometer and DNA extracts were diluted to a final concentration of $5 \mathrm{ng} \mu \mathrm{L}^{-1}$ for analysis via real-time PCR.

\subsection{Real-Time PCR Analysis}

Real-time PCR was performed in reactions of $50 \mu \mathrm{L}$ containing $5 \mu \mathrm{L}$ template, $300 \mathrm{nM}$ of the $V$. isaacii primers or $200 \mathrm{nM}$ of the $V$. longisporum/V. dahliae primers, and $25 \mu \mathrm{L}$ GoTaq qPCR Master Mix containing the CXR reference dye (Promega) to monitor dsDNA synthesis. The primers used to detect and quantify the different Verticillium spp. in the soil and plant samples are listed in Table 6. Amplification and melting curve analysis were performed using the MX3005P real-time PCR Detection System (Stratagene). The thermal profile consisted of $10 \mathrm{~min}$ at $95^{\circ} \mathrm{C}$, followed by 40 cycles of $15 \mathrm{~s}$ at $95^{\circ} \mathrm{C}$ and $1 \mathrm{~min}$ at $60^{\circ} \mathrm{C}$. Melting curves were obtained by heating the samples to $95^{\circ} \mathrm{C}$ for $15 \mathrm{~s}$, cooling to $60^{\circ} \mathrm{C}$ for $15 \mathrm{~s}$ and heating again to $95^{\circ} \mathrm{C}$ for $15 \mathrm{~s}$ to verify specific amplification. Quantification was done using the standard curve technique with a 10-fold dilution series of DNA in sterile water $\left(10-10^{6} \mathrm{fg}\right.$ DNA per reaction) from reference strains Ve005 (V. dahliae) (lab collection), VLO1 (V. longisporum) [2] and Vt305 (V. isaacii) [9].

Table 6. Primers used to detect and quantify Verticillium spp. in plant and soil samples.

\begin{tabular}{ccccc}
\hline Target Organism & Gene Target & Primer & Sequence $\mathbf{( 5}^{\prime}$ to $\mathbf{3}^{\prime}$ ) & Reference \\
\hline V. isaacii & rDNA ITS & VtF4 & CCGGTGTTGGGGATCTACT & {$[45]$} \\
& & VtR2 & GTAGGGGGTTTAGAGGCTG & {$[45]$} \\
V. longisporum & 18S intron rDNA & VlspF1 & AGCCTGAGTCACGAGAGATATGGG & {$[46]$} \\
& & VlspR4 & CAAACCACGCCACTGCATTCTCGT & {$[46]$} \\
V. dahliae & rDNA ITS & VdF1 & CCGCCGGTCCATCAGTCTCTCTG & {$[46]$} \\
& & VdR1 & GGGACTCCGATGCGAGCTGTAAC & {$[46]$} \\
\hline
\end{tabular}

\subsection{Statistical Analysis}

All data of the experiments were analyzed using the software package SPSS 26.0 for windows. The ordinal data of vascular discoloration were analyzed using non-parametric Mann-Whitney comparisons $(p<0.05)$. Data on the colonization by $V$. longisporum and $V$. isaacii and data on the inoculum densities of Verticillium spp. were ln transformed before statistics and further analyzed using Tukey tests $(p<0.05)$. Data on the disease index, the disease incidence and the percentage marketable curds did not meet the conditions of normality and homogeneity of variances and were analyzed using non-parametric Mann-Whitney comparisons $(p<0.05)$.

Author Contributions: Conceptualization, S.D., K.S., S.P., L.D.R., D.C., S.C.F. and M.H.; methodology, S.D., K.S., S.P. and M.H.; software, S.D.; validation, S.D., K.S. and S.P.; formal analysis, S.D.; investigation, S.D., K.S., S.P., and L.T.; resources, L.D.R., D.C. and M.H.; data curation, S.D., K.S. and S.P.; writing—original draft preparation, S.D.; writing-review and editing, K.S., S.P., L.T., L.D.R., D.C., S.C.F. and M.H.; visualization, S.D.; supervision, M.H., L.D.R. and D.C.; project administration, M.H.; funding acquisition, S.C.F., M.H., D.C., L.D.R. All authors have read and agreed to the published version of the manuscript.

Funding: This research was funded by the Government Agency for Innovation in Science and Technology (IWT-Vlaanderen), grant number IWT 100886.

Acknowledgments: The authors are grateful to Ilse Delaere, Nadia Lemeire and Evelien De Waele of the Phytopathology Lab, Department of Plants and Crops, Ghent University, for technical assistance. We also acknowledge Jane Debode of the Research Institute for Agriculture, Fisheries and Food (ILVO), for provision of the facilities for filtering the soil samples.

Conflicts of Interest: The authors declare no conflict of interest. The funders had no role in the design of the study; in the collection, analyses, or interpretation of data; in the writing of the manuscript, or in the decision to publish the results. 


\section{Appendix A}

Fallow 2013

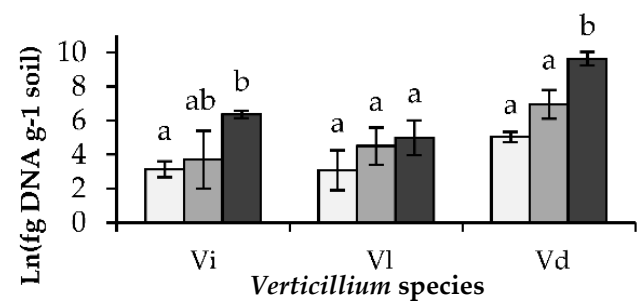

Phacelia 2013

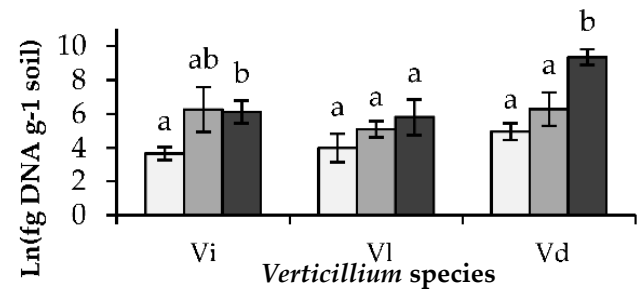

Potato 2013

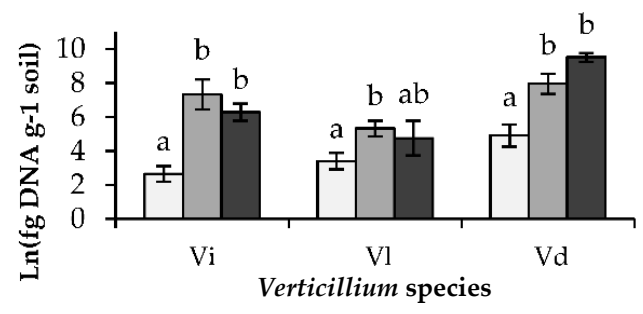

Ryegrass 2013

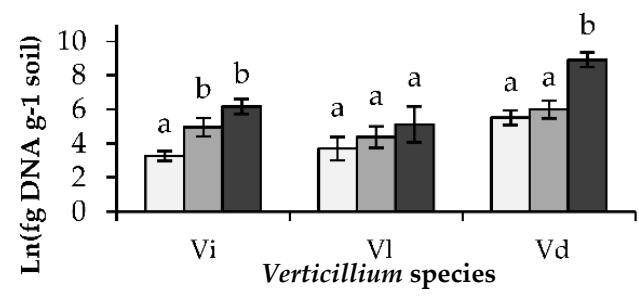

Sticky nightshade 2013

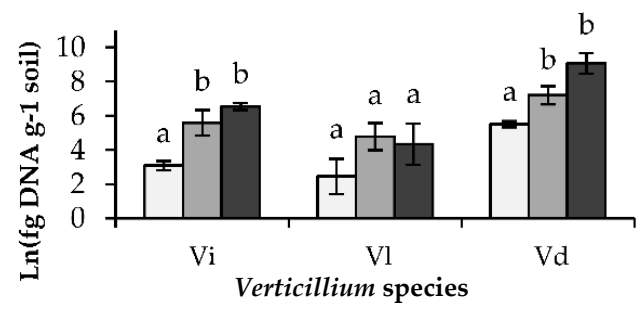

Fallow 2014

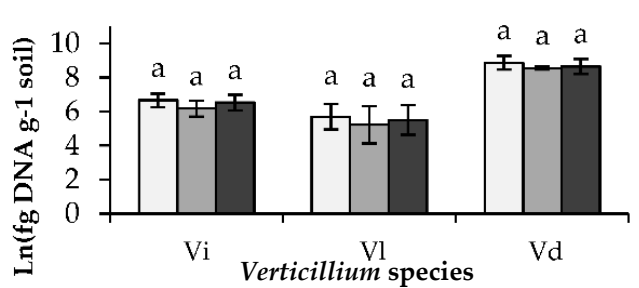

Phacelia 2014

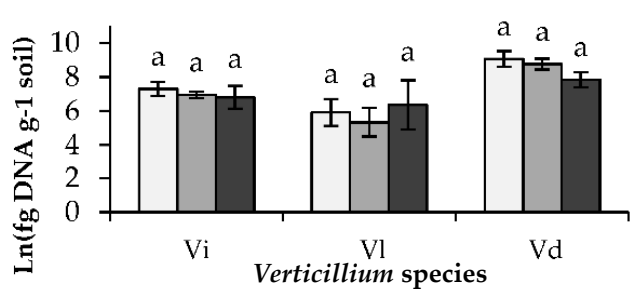

Potato 2014

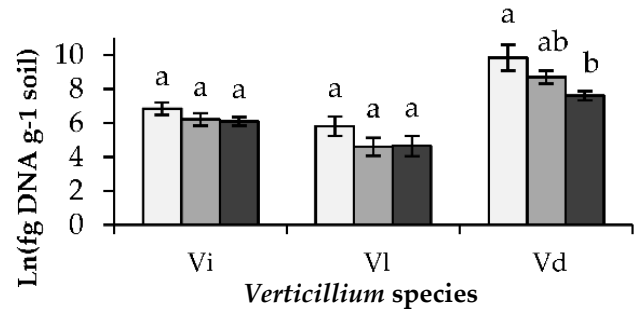

Ryegrass 2014

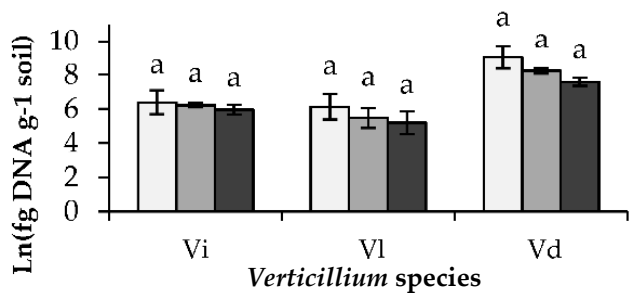

Black oat 2014

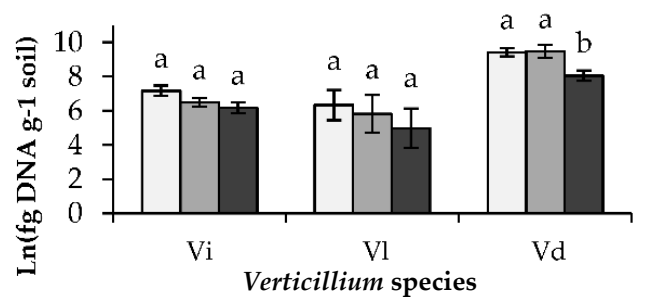

Figure A1. Inoculum densities of $V$. isaacii (Vi), V. longisporum (Vl) and V. dahliae (Vd) at three time points ( $\square$ : sowing/planting of crop 1, $\square$ : incorporation of crop 1 and $\square$ : harvest of cauliflower) in a grower's field located in Ardooie during the growing seasons of 2013 and 2014 in five cover crop systems. Values are the mean of 4 replicates and the vertical bars represent the standard error of the mean. Data were $\ln$ transformed before statistics. For each Verticillium species, bars with different letters indicate statistical differences according to Tukey tests $(p<0.05)$. 
Fallow 2013

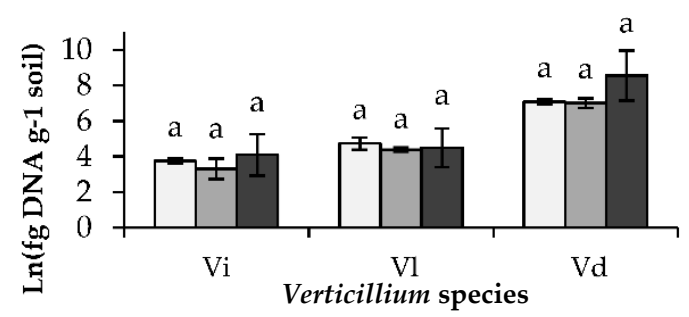

Phacelia 2013

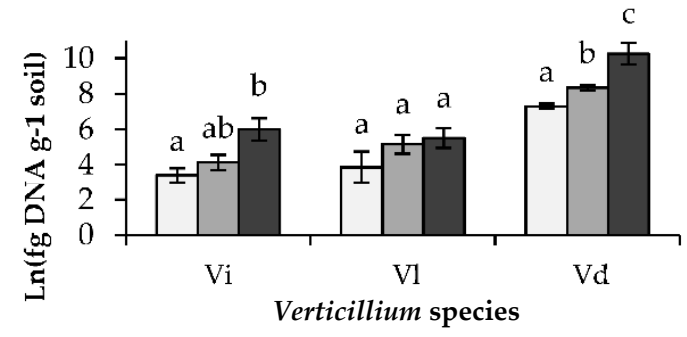

Potato 2013

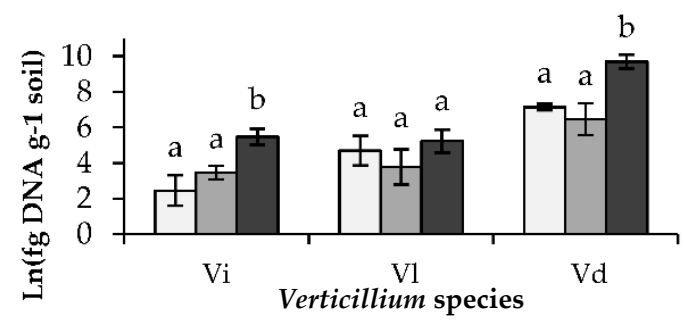

Ryegrass 2013

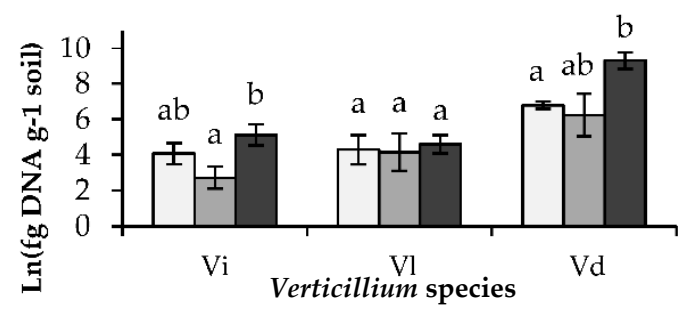

Sticky nightshade 2013

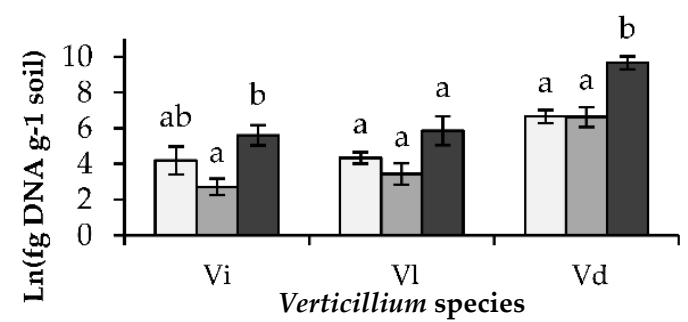

Fallow 2014

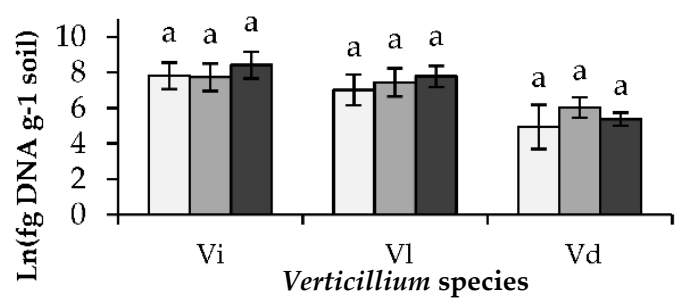

Phacelia 2014

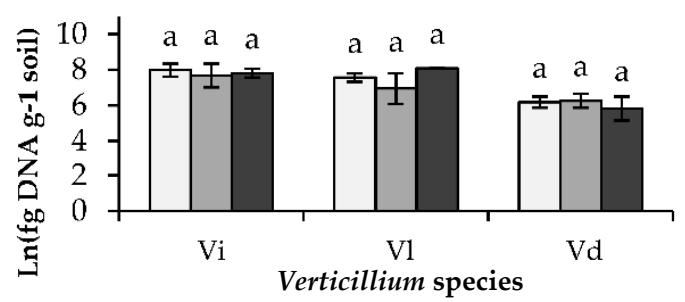

Potato 2014

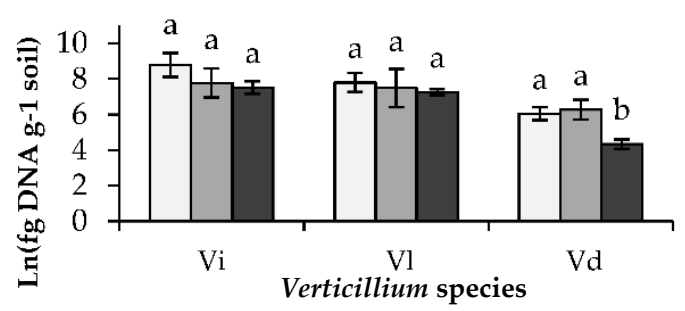

Ryegrass 2014

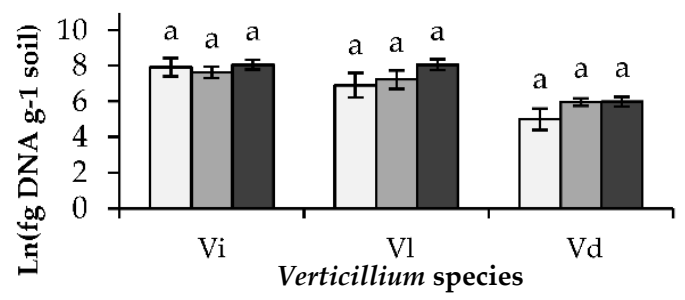

Black oat 2014

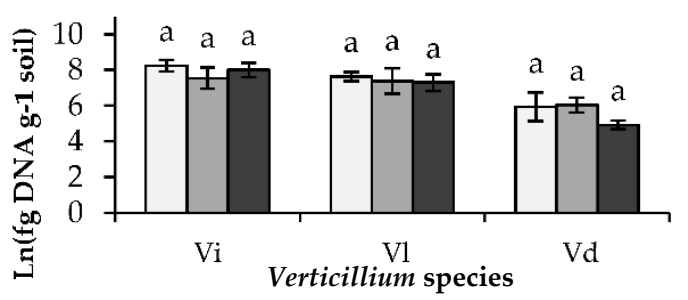

Figure A2. Inoculum densities of $V$. isaacii (Vi), V. longisporum (Vl) and V. dahliae (Vd) at three time points ( $\square$ : sowing/planting of crop 1, $\square$ : incorporation of crop 1 and $\square$ : harvest of cauliflower) in a grower's fields located in Puurs during the growing seasons of 2013 and 2014 in five cover crop systems. Values are the mean of 4 replicates and the vertical bars represent the standard error of the mean. Data were $\ln$ transformed before statistics. For each Verticillium species, bars with different letters indicate statistical differences according to Tukey tests $(p<0.05)$. 
Fallow

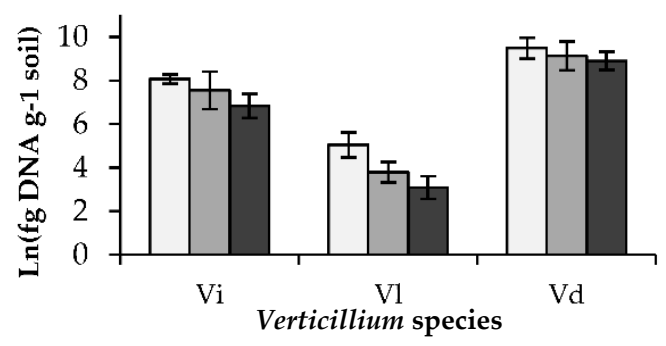

Ryegrass

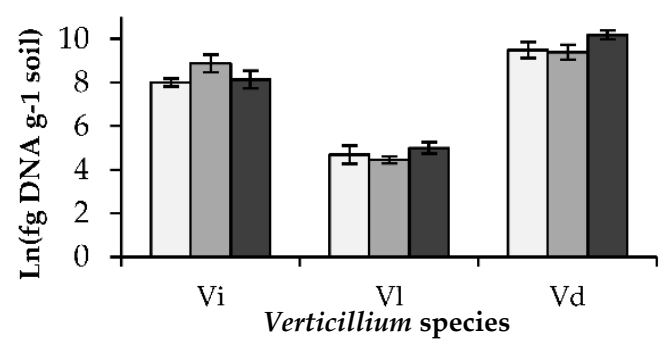

Phacelia

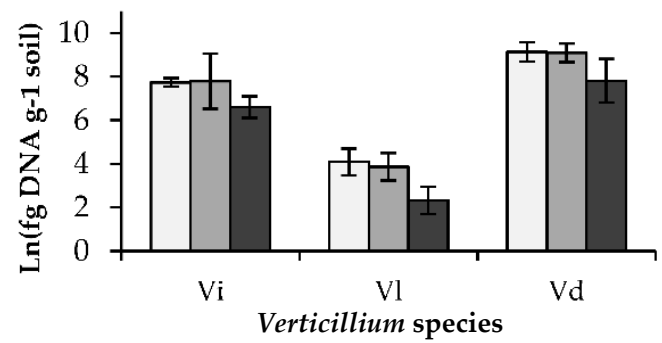

Black oat

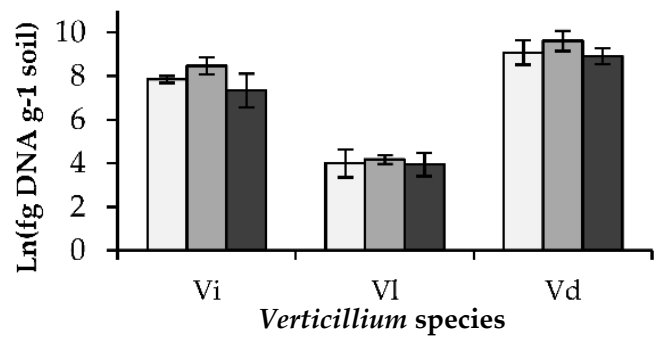

Fallow + Vt305

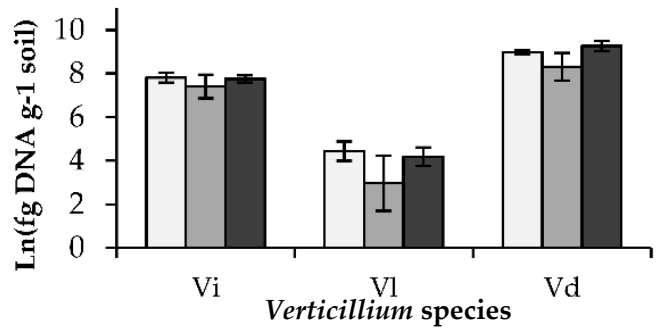

Ryegrass + Vt305

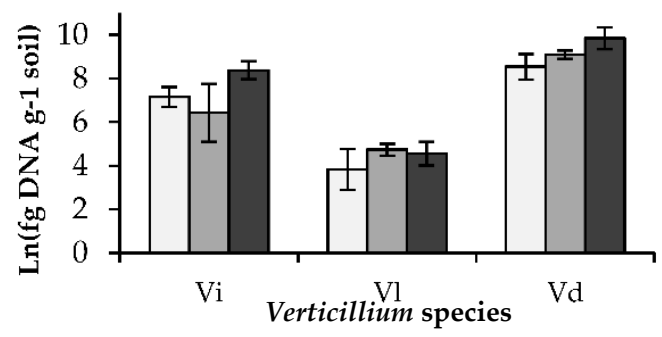

Phacelia + Vt305

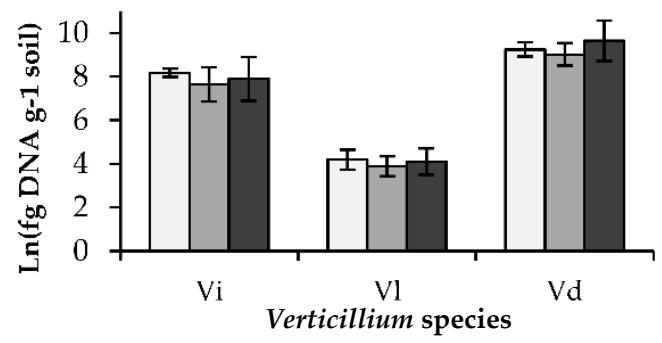

Black oat + Vt305

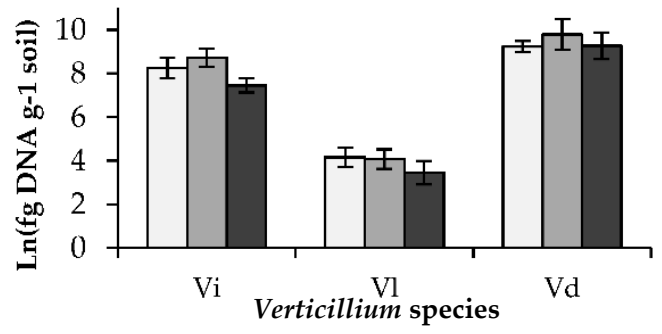

Figure A3. Inoculum densities of $V$. isaacii (Vi), V. longisporum $(\mathrm{Vl})$ and $V$. dahliae $(\mathrm{Vd})$ at three time points ( $\square$ : sowing/planting of crop 1, $\square$ : incorporation of crop 1 and $\square$ : harvest of cauliflower) in a grower's field located in Puurs during the growing season of 2015 in four cover crop systems and two treatment systems of the cauliflower seeds (left panel: no seed treatment; right panel: seed treatment with $V$. isaacii Vt305 microsclerotia indicated by ' $+\mathrm{Vt} 305$ '). Cauliflower seeds were treated with $0.5 \mathrm{~mL}$ of tap water (control plants) or $0.5 \mathrm{~mL}$ of a microsclerotia (MS) suspension of $V$. isaacii Vt305 resulting in $500 \mathrm{MS}$ per seed. Values are the mean of 4 replicates and the vertical bars represent the standard error of the mean. Data were $\ln$ transformed before statistics. No statistical differences were detected for the different Verticillium species in the different growing systems using Tukey tests $(p<0.05)$. 


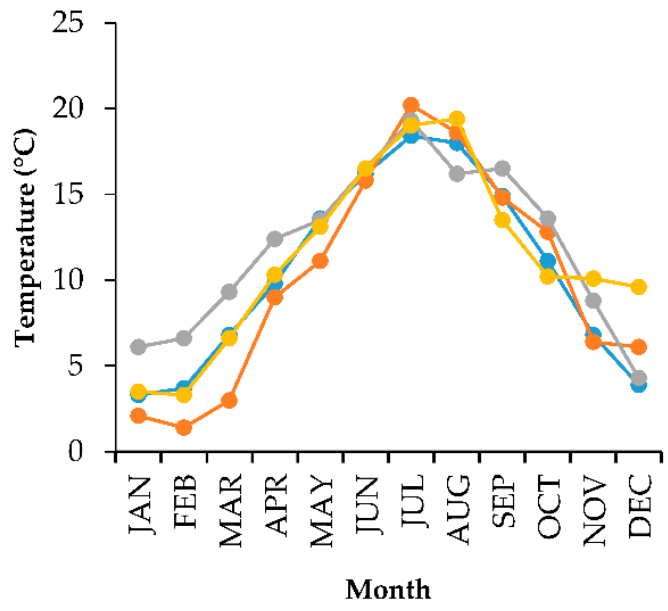

$\multimap$ Normal $\multimap 2013 \multimap 2014 \longrightarrow 2015$

(A)

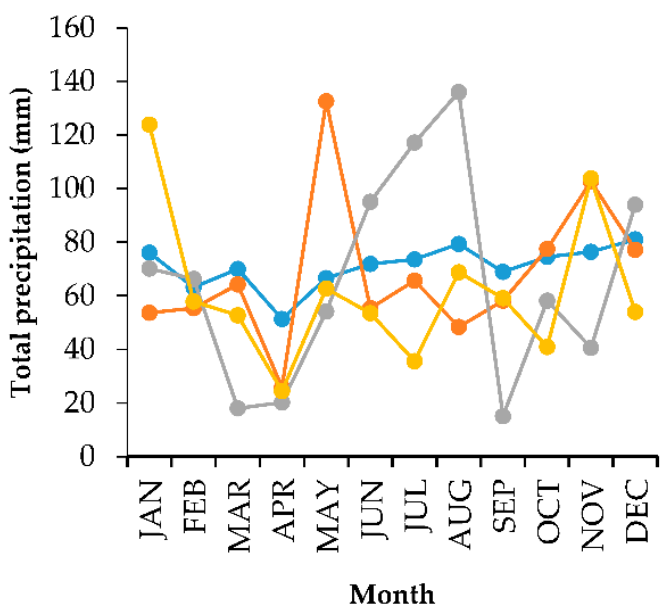

$\longrightarrow$ Normal $\multimap 2013 \multimap 2014 \multimap 2015$

Figure A4. Meteorological data measured in Ukkel in 2013, 2014 and 2015. (A) Mean monthly temperature; (B) Total monthly precipitation [47].

\section{References}

1. Koike, S.T.; Subbarao, K.V.; Davis, R.M.; Gordon, T.R.; Hubbard, J.C. Verticillium wilt of cauliflower in California. Plant Dis. 1994, 78, 1116-1121. [CrossRef]

2. Debode, J.; Clewes, E.; De Backer, G.; Höfte, M. Lignin is involved in the reduction of Verticillium dahliae var. longisporum inoculum in soil by crop residue incorporation. Soil Biol. Biochem. 2005, 37, 301-309. [CrossRef]

3. Debussche, B. Areaal openluchtgroenten gaat opnieuw de hoogte in. Proeftuinnieuws Jaargang 30 2020, 16, 46-47.

4. Deketelaere, S.; Tyvaert, L.; Franca, S.C.; Höfte, M. Desirable traits of a good biocontrol agent against Verticillium wilt. Front. Microbiol. 2017, 8, 23. [CrossRef] [PubMed]

5. Abuamsha, R.; Salman, M.; Ehlers, R.U. Differential resistance of oilseed rape cultivars (Brassica napus ssp oleifera) to Verticillium longisporum infection is affected by rhizosphere colonisation with antagonistic bacteria, Serratia plymuthica and Pseudomonas chlororaphis. Biocontrol 2011, 56, 101-112. [CrossRef]

6. Berg, G.; Marten, P.; Ballin, G. Stenotrophomonas maltophilia in the rhizosphere of oilseed rape-Occurrence, characterization and interaction with phytopathogenic fungi. Microbiol. Res. 1996, 151, 19-27. [CrossRef]

7. Danielsson, J.; Reva, O.; Meijer, J. Protection of oilseed rape (Brassica napus) toward fungal pathogens by strains of plant-associated Bacillus amyloliquefaciens. Microb. Ecol. 2007, 54, 134-140. [CrossRef]

8. Müller, H.; Berg, G. Impact of formulation procedures on the effect of the biocontrol agent Serratia plymuthica HRO-C48 on Verticillium wilt in oilseed rape. Biocontrol 2008, 53, 905-916. [CrossRef]

9. França, S.C.; Spiessens, K.; Pollet, S.; Debode, J.; De Rooster, L.; Callens, D.; Höfte, M. Population dynamics of Verticillium species in cauliflower fields: Influence of crop rotation, debris removal and ryegrass incorporation. Crop Prot. 2013, 54, 134-141. [CrossRef]

10. Inderbitzin, P.; Bostock, R.M.; Davis, R.M.; Usami, T.; Platt, H.W.; Subbarao, K.V. Phylogenetics and taxonomy of the fungal vascular wilt pathogen Verticillium, with the descriptions of five new species. PLoS ONE 2011, 6, 22. [CrossRef]

11. Tyvaert, L.; França, S.C.; Debode, J.; Höfte, M. The endophyte Verticillium Vt305 protects cauliflower against Verticillium wilt. J. Appl. Microbiol. 2014, 116, 1563-1571. [CrossRef] [PubMed]

12. Davis, J.R.; Pavek, J.J.; Corsini, D.L. Potato genotypes, a tool for managing soilborne pathogens-A summary. In Managing Soil-Borne Pathogens: A Sound Rhizosphere to Improve Productivity in Intensive Horticultural Systems; Vanachter, A., Ed.; International Society Horticultural Science: Leuven, Belgium, 2004; Volume 1, pp. 93-100. [CrossRef] 
13. Cherr, C.M.; Scholberg, J.M.S.; McSorley, R. Green manure approaches to crop production: A synthesis. Agron. J. 2006, 98, 302-319. [CrossRef]

14. Abadie, C.; Edel, V.; Alabouvette, C. Soil suppressiveness to Fusarium wilt: Influence of a cover-plant on density and diversity of Fusarium populations. Soil Biol. Biochem. 1998, 30, 643-649. [CrossRef]

15. Bulluck, L.R.; Ristaino, J.B. Effect of synthetic and organic soil fertility amendments on southern blight, soil microbial communities, and yield of processing tomatoes. Phytopathology 2002, 92, 181-189. [CrossRef] [PubMed]

16. Wiggins, B.E.; Kinkel, L.L. Green manures and crop sequences influence alfalfa root rot and pathogen inhibitory activity among soil-borne Streptomycetes. Plant Soil 2005, 268, 271-283. [CrossRef]

17. Wiggins, B.E.; Kinkel, L.L. Green manures and crop sequences influence potato diseases and pathogen inhibitory activity of indigenous Streptomycetes. Phytopathology 2005, 95, 178-185. [CrossRef]

18. Pegg, G.F.; Brady, B.L. Verticillium Wilts; CABI Publishing: Wallingford, UK, 2002.

19. Timmermans, B.G.H.; Vos, J.; Stomph, T.J. The development, validation and application of a crop growth model to assess the potential of Solanum sisymbriifolium as a trap crop for potato cyst nematodes in Europe. Field Crop. Res. 2009, 111, 22-31. [CrossRef]

20. Lima, E.A.; Mattos, J.K.; Moita, A.W.; Carneiro, R.G.; Carneiro, R.M.D.G. Host status of different crops for Meloidogyne ethiopica control. Trop. Plant Pathol. 2009, 34, 152-157. [CrossRef]

21. Schnathorst, W.C.; Mathre, D.E. Cross-protection in cotton with strains of Verticillium albo-atrum. Phytopathology 1966, 56, 1204-1209.

22. Zhu, H.-Q.; Feng, Z.-L.; Li, Z.-F.; Shi, Y.-Q.; Zhao, L.-H.; Yang, J.-R. Characterization of two fungal isolates from cotton and evaluation of their potential for biocontrol of Verticillium wilt of cotton. J. Phytopathol. 2013, 161, 70-77. [CrossRef]

23. Davis, J.R.; Everson, D.O.; Sorensen, L.H.; Schneider, A.T. Associations of Verticillium Tricorpus with Soil Suppressiveness of Verticillium Wilt of Potato; American Phytopathological Society: St Paul, MN, USA, 2000; pp. 347-351.

24. Robinson, N.; Platt, H.W.; Hale, L.R. Interactions of various Verticillium species in combination with V. albo-atrum on Verticillium wilt disease development in potato. Am. J. Potato Res. 2007, 84, 133-141. [CrossRef]

25. Matta, A.; Garibaldi, A. Control of Verticillium wilt of tomato by preinoculation with avirulent fungi. Neth. J. Plant Pathol. 1977, 83, 457-462. [CrossRef]

26. Shittu, H.O.; Castroverde, D.C.M.; Nazar, R.N.; Robb, J. Plant-endophyte interplay protects tomato against a virulent Verticillium. Planta 2009, 229, 415-426. [CrossRef]

27. Qin, Q.M.; Vallad, G.E.; Subbarao, K.V. Characterization of Verticillium dahliae and V. tricorpus isolates from lettuce and artichoke. Plant Dis. 2008, 92, 69-77. [CrossRef] [PubMed]

28. García, M.; Arriagada, C.; Garcia-Romera, I.; Ocampo, J.A. Are plant cell wall hydrolysing enzymes of saprobe fungi implicated in the biological control of the Verticillium dahliae pathogenesis? Crop Prot. 2011, 30, 85-87. [CrossRef]

29. Wilhelm, S. Longevity of the Verticillium wilt fungus in the laboratory and field. Phytopathology 1955, 45, 180-181.

30. Whipps, J.M.; McQuilken, M.P. Biological control agents in plant disease control. In Disease Control in Crops; Walters, D., Ed.; Wiley-Blackwell: Hoboken, NJ, USA, 2009; pp. 27-61. [CrossRef]

31. Debode, J.; Declercq, B.; Höfte, M. Identification of cauliflower cultivars that differ in susceptibility to Verticillium longisporum using different inoculation methods. J. Phytopathol. 2005, 153, 257-263. [CrossRef]

32. Brinkerhoff, L.A. The influence of temperature, aeration, and soil microflora on microsclerotial development of Verticillium albo-atrum in abscised cotton leaves. Phytopathology 1969, 59, 805-808.

33. Davis, J.R.; Huisman, O.C.; Everson, D.O.; Nolte, P.; Sorenson, L.H.; Schneider, A.T. The suppression of Verticillium wilt of potato using corn as a green manure crop. Am. J. Potato Res. 2010, 87, 195-208. [CrossRef]

34. Mol, L.; Scholte, K. Effect of haulm treatments on the formation of microsclerotia of Verticillium dahliae Kleb on potato. Potato Res. 1995, 38, 151-157. [CrossRef]

35. Davis, J.R.; Huisman, O.C.; Westermann, D.T.; Hafez, S.L.; Everson, D.O.; Sorensen, L.H.; Schneider, A.T. Effects of green manures on Verticillium wilt of potato. Phytopathology 1996, 86, 444-453. [CrossRef] 
36. Ochiai, N.; Powelson, M.L.; Dick, R.P.; Crowe, F.J. Effects of green manure type and amendment rate on Verticillium wilt severity and yield of Russet Burbank potato. Plant Dis. 2007, 91, 400-406. [CrossRef] [PubMed]

37. England, L.S.; Holmes, S.B.; Trevors, J.T. Persistence of viruses and DNA in soil. World J. Microbiol. Biotechnol. 1998, 14, 163-169. [CrossRef]

38. Lievens, B.; Brouwer, M.; Vanachter, A.; Lévesque, C.A.; Cammue, B.P.A.; Thomma, B.P.H.J. Quantitative assessment of phytopathogenic fungi in various substrates using a DNA macroarray. Environ. Microbiol. 2005, 7, 1698-1710. [CrossRef]

39. Schena, L.; Ippolito, A. Rapid and sensitive detection of Rosellinia necatrix in roots and soils by real time Scorpion-PCR. J. Plant Pathol. 2003, 85, 15-25.

40. Davis, J.R.; Huisman, O.C.; Everson, D.O.; Schneider, A.T. Verticillium wilt of potato: A model of key factors related to disease severity and tuber yield in southeastern Idaho. Am. J. Potato Res. 2001, 78, 291-300. [CrossRef]

41. Gurung, S.; Short, D.P.G.; Hu, X.P.; Sandoya, G.V.; Hayes, R.J.; Koike, S.T.; Subbarao, K.V. Host range of Verticillium isaacii and Verticillium klebahnii from artichoke, spinach, and lettuce. Plant Dis. 2015, 99, 933-938. [CrossRef]

42. Powell, M.; Gundersen, B.; Miles, C.; Coats, K.; Inglis, D.A. First report of Verticillium wilt on lettuce (Lactuca sativa) in Washington caused by Verticillium tricorpus. Plant Dis. 2013, 97, 996-997. [CrossRef]

43. Wheeler, D.L.; Johnson, D.A. Verticillium isaacii is a pathogen and endophyte of potato and sunflower in the Columbia Basin of Washington. Plant Dis. 2019, 103, 3150-3153. [CrossRef]

44. López-Escudero, F.J.; Mwanza, C.; Blanco-López, M.A. Production of homogeneous and viable Verticillium dahliae microsclerotia effective for Verticillium wilt studies. Biotechnology 2006, 5, 421-428. [CrossRef]

45. Debode, J.; Van Poucke, K.; França, S.C.; Maes, M.; Höfte, M.; Heungens, K. Detection of multiple Verticillium species in soil using density flotation and real-time Polymerase Chain Reaction. Plant Dis. 2011, 95, 1571-1580. [CrossRef] [PubMed]

46. Banno, S.; Saito, H.; Sakai, H.; Urushibara, T.; Ikeda, K.; Kabe, T.; Kemmochi, I.; Fujimura, M. Quantitative nested real-time PCR detection of Verticillium longisporum and V. dahliae in the soil of cabbage fields. J. Gen. Plant Pathol. 2011, 77, 282-291. [CrossRef]

47. KMI. Available online: https://www.meteo.be/nl/klimaat/klimatologisch-overzicht/2011-2015 (accessed on 20 July 2020).

Publisher's Note: MDPI stays neutral with regard to jurisdictional claims in published maps and institutional affiliations.

(C) 2020 by the authors. Licensee MDPI, Basel, Switzerland. This article is an open access article distributed under the terms and conditions of the Creative Commons Attribution (CC BY) license (http://creativecommons.org/licenses/by/4.0/). 